Article

\title{
An Innovative Approach to Manganese-Substituted Hydroxyapatite Coating on Zinc Oxide-Coated 316L SS for Implant Application
}

\author{
Karuppasamy Prem Ananth 1,2,*, Jinxing Sun ${ }^{1,2}$ and Jiaming Bai 1,2,* \\ 1 Shenzhen Key Laboratory for Additive Manufacturing of High-Performance Materials, \\ Shenzhen 518055, China; sjx476526525@163.com \\ 2 Department of Mechanical and Energy Engineering, Southern University of Science and Technology, \\ Shenzhen 518055, China \\ * Correspondence: kpananth01@gmail.com (K.P.A.); baijm@sustc.edu.cn (J.B.); \\ Tel.: +86-136-8646-1595 (K.P.A.); +86-755-8801-5354 (J.B.)
}

Received: 2 July 2018; Accepted: 23 July 2018; Published: 9 August 2018

\begin{abstract}
In this paper, the synthesis of porous manganese substituted hydroxyapatite (Mn-HAp) coating on zinc oxide $(\mathrm{ZnO})$ coated stainless steel (316L SS) using the electrodeposition technique is reported. The structural, functional, morphological, and elemental analyses are characterized by various analytical techniques including X-ray diffraction (XRD), Fourier transform infrared spectroscopy (FT-IR), field emission scanning electron microscopy (FE-SEM), transmission electron microscopy (TEM), and X-ray photoelectron spectroscopy (XPS). Results of electrochemical techniques such as cyclic polarization and impedance show that the Mn-HAp coating on $\mathrm{ZnO}$ coated 316L SS has the highest corrosion resistance in simulated body fluid (SBF) solution. Moreover, dissolution of metal ions was extremely reduced, as evaluated by inductively coupled plasma-atomic emission spectroscopy (ICP-AES). The adhesion and hardness of Mn-HAp/ZnO bilayer coatings have superior mechanical properties over individual coatings. Further, the biocompatibility of in vitro osteoblast attachment, cell viability, and live/dead assessment also confirmed the suitability of Mn-HAp/ZnO bilayer coating on 316L SS for orthopedic applications.
\end{abstract}

Keywords: hydroxyapatite; corrosion zinc oxide; electrodeposition; bilayer coating; biomedical implant

\section{Introduction}

Metals have been used for implant applications since 1895. Currently, stainless steel (316L SS) is the most used alloy in orthopedic and dental implant applications, owing to its high corrosion protection, excellent mechanical strength, good processsability, biocompatibility, and low cost [1]. This material is employed in load-bearing applications such as bone fixation and total joint replacement in the human body [2]. However, the constant involvement of its corrosive nature and biocompatibility in physiological mediums is significant, since a corrosive metal can be very harmful to the human body, and 316L SS metal might create localized corrosion in the body [3]. In some cases, metallic ions released from 316L SS, such as iron, chromium, and nickel, can accumulate in neighboring tissues, and local systemic effects could affect their proliferation and differentiation [4]. Therefore, in order to overcome the adverse reactions in the human body and to increase the lifespan of implanted orthopedic devices, surface treatment of metals is often required.

Coating the surfaces of implant devices with an organic self-assembled monolayer [5], glass [6], or ceramic is an effective method of corrosion protection [7,8]. At present, the focus is on zinc oxide $(\mathrm{ZnO})$ coating, which has attracted interest due to its excellent anticorrosion properties and 
potential in implant applications [9]. Since $\mathrm{ZnO}$ nanoparticles are nontoxic, they can be used to produce environmentally friendly coatings, and they also have excellent optical, chemical, mechanical, and biological properties [10,11]. Several attempts have been made to use nanosized (small size and high surface area) particle coatings on implant devices. As mentioned above, such coatings would be corrosion protective, a significant advantage [12,13].

Calcium phosphate (CaP)-based bioceramics, particularly hydroxyapatite (HAp), are basic inorganic components for hard biological tissues such as bones and teeth due to their close resemblance to the mineral phase and crystalline structure $[14,15]$. The application of bioactive calcium phosphate (Cap) coatings could supply increased amounts of $\mathrm{Ca}^{2+}$ and $\mathrm{PO}_{4}{ }^{3-}$ in initial stages of implantation, and thus the transformation to a smaller amount of soluble biocompatible hydroxyapatite can be achieved [16]. HAp has two crystal forms: (i) monoclinic, space group $\mathrm{P} 2_{1} / \mathrm{b}$, and (ii) hexagonal, space group $\mathrm{P}_{3} / \mathrm{m}$. Only the hexagonal phase is of practical significance, because the monoclinic form is weakened by the presence of even small amounts of foreign ions [17]. Normally, human bone contains trace amounts of minerals such as sodium $(\mathrm{Na}+)$, magnesium $\left(\mathrm{Mg}^{2+}\right)$, strontium $\left(\mathrm{Sr}^{2+}\right)$, zinc $\left(\mathrm{Zn}^{2+}\right)$, silicon $\left(\mathrm{Si}^{4+}\right)$, and manganese $\left(\mathrm{Mn}^{2+}\right)[18,19]$. The substitution of ions in such species is considered to have a significant influence on the physical, chemical, and physiological properties of solid bones and teeth and subsequently on the mineralization, demineralization, and remineralization process of calcified tissues [20,21]. Among the various ion substitutions, manganese $\left(\mathrm{Mn}^{2+}\right)$ substituted HAp significantly improves the superiority of bone repair in biotechnological coatings [22]. Hence, incorporating manganese into the apatite structure is of great interest because of its improvement in mechanical properties, controlled cell interactions with the extracellular matrix, and activation of cellular adhesion [23]. Many coating techniques have been applied to improve the corrosion resistance of 316L SS in physiological fluids, among which plasma spraying [24], dip coating [25], sputter coating [26], biomimetic coating [27], and electrophoretic deposition are widely investigated [28]. The electrodeposition technique is one of the prominent coating methods because of fabrication at low process temperature, process simplicity, and uniformity of deposition $[29,30]$. It has been reported that porous HAp coating can be achieved at high current densities between 5 and $9 \mathrm{~mA} / \mathrm{cm}^{2}$ by the electrodeposition method [31].

The purpose of this bilayer coating was to discover the corrosion protection behavior of an electrodeposition of the coating in simulated body fluid (SBF) solution. Hence the present work was designed in such a way that Mn-HAp coating on $\mathrm{ZnO}$ coated 316L SS alloy improved corrosion resistance, mechanical strength, and biological properties. There are no previous reports available on $\mathrm{Mn}-\mathrm{HAp} / \mathrm{ZnO}$ bilayer coating on 316L SS. This is anticipated to be a superior appropriate alternative material for orthopedic implant compared to the existing coating materials.

\section{Result and Discussion}

\subsection{Field Emission Scanning Electron Microscopy (FE-SEM) Analysis}

The difference of barriers created by the spherical, lamellar, and combined structure coated on 316L SS substrate model is shown in Figure 1a-c. The developed spherical and lamellar shaped ZnO coatings show a favorable improvement as a barrier against corrosion [32]. Figure 1a-c shows field emission scanning electron microscopy (FESEM) images of ZnO, Mn-HAp, and Mn-HAp/ZnO bilayer coating on 316L SS, and Figure $1 \mathrm{~d}$ gives cross-sectional images of the bilayer coating. Figure $1 \mathrm{~d}$ displays the spherical and lamellar shaped $\mathrm{ZnO}$ nanoparticles agglomerated with uniformly stiffened grains on 316L SS surface. This small spherical morphology of the particles supports the better anticorrosive coating properties $[33,34]$. Figure 1e exhibits the formation of the rough microstructure of Mn-HAp on 316L SS. The uniform distribution of the interconnected porous network of Mn-HAp/ZnO is demonstrated in Figure 1f. The interconnected pores, which allow the attachment and proliferation of diverse cell types, are responsible for the formation of functional tissues and support of bone growth [35]. Figure 1g shows a cross-sectional view of the Mn-HAp/ZnO bilayer coating on 316L SS, 
with a thickness of $184 \mu \mathrm{m}$. The cross-sectional layer is continuous without cracks or breaks throughout its length.

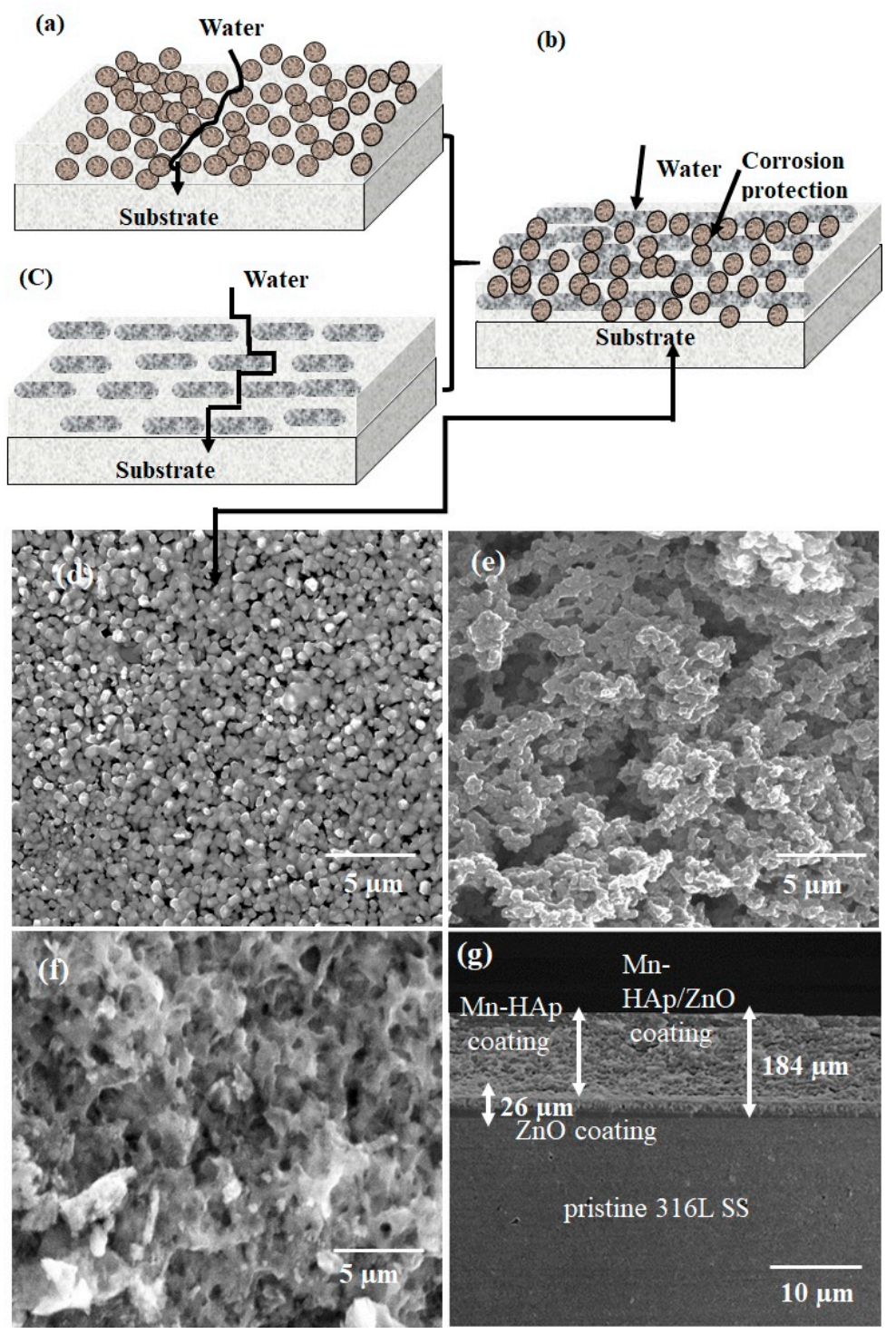

Figure 1. (a-c) Spherical, lamellar, and combined zinc oxide $(\mathrm{ZnO})$ structure coated stainless steel (316L SS) substrate. Field emission scanning electron microscopy (FESEM) images of (d) ZnO, (e) porous manganese substituted hydroxyapatite (Mn-HAp), and (f) Mn-HAp/ZnO bilayer coatings on 316L SS and $(\mathrm{g})$ cross-sectional FESEM image of Mn-HAp/ZnO bilayer coating on 316L SS.

2.2. Transmission Electron Microscopy (TEM), High-Resolution Transmission Electron Microscopy (HRTEM), and Selected Aread Electron Difraction (SAED) Pattern

Transmission electron microscopy (TEM), high-resolution TEM (HRTEM), and SAED patterns of $\mathrm{ZnO}, \mathrm{Mn}-\mathrm{HAp}$, and Mn-HAp/ZnO coatings on 316L SS specimens are depicted in Figure 2a-i. Figure 2a shows the spherical and lamellar shaped $\mathrm{ZnO}$ merged with the substrate along with small clusters embedded in the substrate. The average size of the $\mathrm{ZnO}$ nanoparticles is observed to be $\sim 15 \mathrm{~nm}$. From Figure 2b, the HRTEM image suggests that interplanar distances of 0.262 and $0.243 \mathrm{~nm}$ correspond to the (002) and (101) planes of wurtzite $\mathrm{ZnO}$. This is further supported by the formation of a distinguishable ring pattern representing 101, 002, 102, 110 and 112 planes of the SAED pattern (Figure 2c). Figure 2d-f shows the TEM, HRTEM, and SAED patterns of Mn-HAp coating 
on 316L SS. The TEM image shows uniform agglomeration of porous structure, and the HRTEM exhibits the lattice fringe image in 002 direction, indicating the hexagonal structure of HAp.

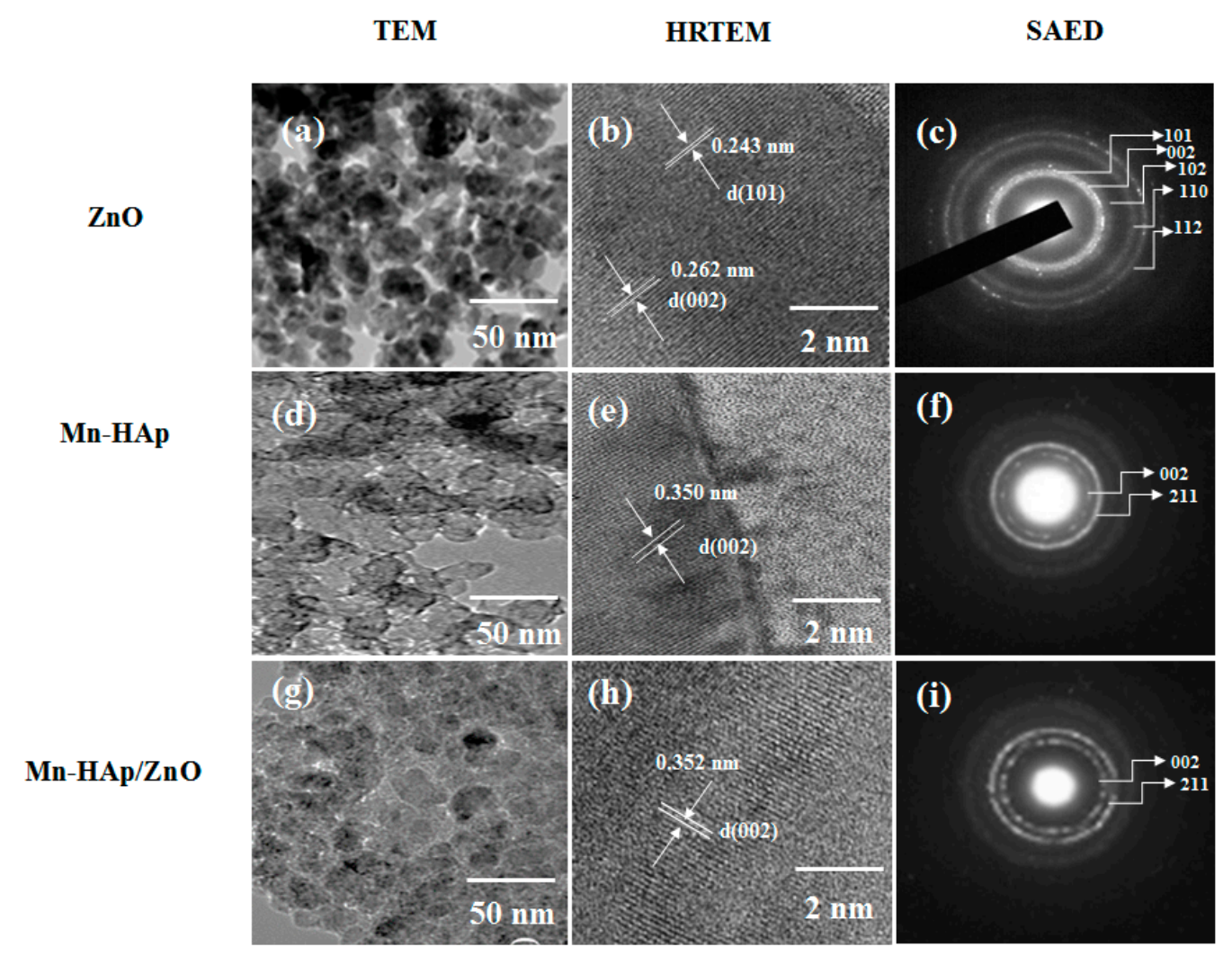

Figure 2. Transmission electron microscopy (TEM), high-resolution TEM (HRTEM), and SAED patterns of (a-c) $\mathrm{ZnO},(\mathbf{d}-\mathbf{f}) \mathrm{Mn}-\mathrm{HAp}$ and (g-i) Mn-HAp/ZnO bilayer coating on 316L SS.

The interplanar $\mathrm{d}$ spacing value is $0.350 \mathrm{~nm}$, which corresponds to the 002 reflection of a hydroxyapatite phase. The spots corresponding to the (002) faces of Mn-HAp are notably brighter, which suggests an orientation of the Mn-HAp porous structure on the 316L SS substrate. Figure $2 \mathrm{~g}-\mathrm{i}$ shows the Mn-HAp/ZnO bilayer coating on 316L SS substrate. The strong porous coatings are observed in Figure $2 \mathrm{~g}$ in the TEM images. Figure 2h (HRTEM) indicates the bilayer coatings in virtual settlement with the polycrystalline lattice structure of HAp. However, there is no obvious diffraction in the SAED patterns when compared to the individual coatings of Mn-HAp. Figure 2i shows the SAED images of bilayer coating, and the interplanar spacing (d) is $0.352 \mathrm{~nm}$ corresponding to the 002 reflection of apatite phase.

\subsection{X-ray Diffraction (XRD) Analysis}

Figure 3a-d shows X-ray diffraction (XRD) patterns for the ZnO, HAp, Mn-HAp, and Mn-HAp/ZnO bilayer coating on 316L SS alloy. From the diffraction pattern in Figure 3a, it can be observed that peak position at $2 \theta=33.18^{\circ}, 35.06^{\circ}, 37.46^{\circ}, 49.21^{\circ}$ and $52.24^{\circ}$ correspond to (110), (002), (101), (102) and (110) reflection planes, respectively. This is in accordance with $\mathrm{ZnO}$ wurtzite structure corresponding to standard Joint Committee on Powder Diffraction Standards (JCPDS) (\#36-1451). 


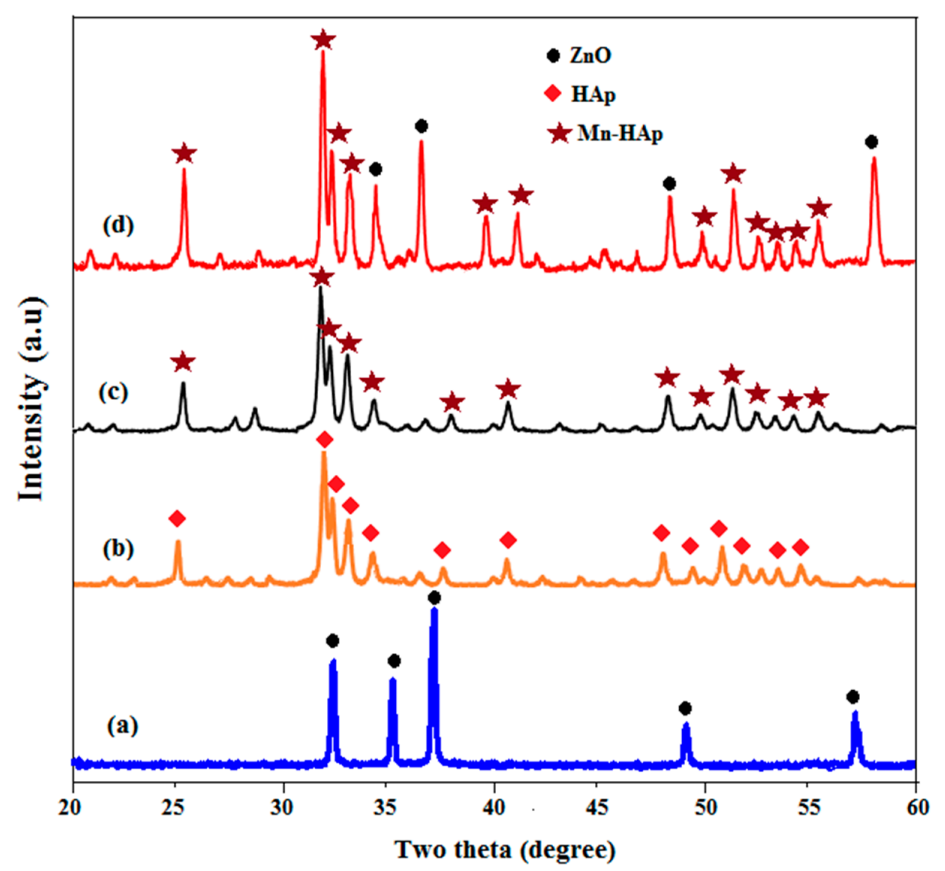

Figure 3. X-ray diffraction (XRD) patterns of (a) ZnO, (b) HAp, (c) Mn-HAp, and (d) Mn-HAp/ZnO bilayer coating on 316L SS.

The sharp reflection peaks indicate good crystallinity of the coated samples. The three high-intensity peaks in Figure $3 \mathrm{~b}$, located at $2 \theta=31.9^{\circ}, 32.8^{\circ}$ and $32.10^{\circ}$, and the corresponding hkl values (211), (112) and (300) were due to the HAp coating on 316L SS. Figure 3c shows the XRD pattern of Mn-HAp coating on 316L SS alloy. The substitution of Mn ion into the HAp did not affect the diffraction pattern, except some changes in peak width and intensity, indicating the presence of Mn ions in HAp. The XRD pattern of Mn-HAp/ZnO bilayer coating on 316L SS is shown in Figure 3d. The observed intense peak $2 \theta$ values of 25.50, 31.41, 33.20, 39.43, 46.82 and 49.68, corresponding to HAp (002), (211), (222), (212), (222) and (213) reflection planes, respectively, were assigned to Mn-HAp, whereas the remaining peaks indicate the (002), (101), (102) and (110) hkl planes, which were assigned to the $\mathrm{ZnO}$ of bilayer coating. This combination of two hkl values was confirmed by bilayer coating on 316L SS substrate.

\subsection{Fourier Transform Infrared Spectroscopy (FT-IR) Analysis}

Figure 4a-d shows the Fourier transform infrared spectroscopy analysis of $\mathrm{ZnO}, \mathrm{HAp}, \mathrm{Mn}-\mathrm{HAp}$, and $\mathrm{Mn}-\mathrm{HAp} / \mathrm{ZnO}$ bilayer coating on 316L SS alloy. Figure 4a shows $\mathrm{ZnO}$ coating on 316L SS, with the characteristic absorption band at $440 \mathrm{~cm}^{-1}$ attributed to $\mathrm{ZnO}$ stretching vibration mode [36]. The bond located at $3465 \mathrm{~cm}^{-1}$ indicates the stretching vibration of the $\mathrm{O}-\mathrm{H}$ bond. The weak band near $1512 \mathrm{~cm}^{-1}$ is assigned to $\mathrm{H}-\mathrm{O}-\mathrm{H}$ bending vibration. Figure $4 \mathrm{~b}$ shows FTIR spectrum of HAp coated on 316L SS. The characteristic peaks $\mathrm{PO}_{4}{ }^{3-}$ were located at $1084 \mathrm{~cm}^{-1}\left(\mathrm{v}_{3}\right), 596 \mathrm{~cm}^{-1}\left(\mathrm{v}_{4}\right)$, and $468 \mathrm{~cm}^{-1}\left(\mathrm{v}_{2}\right), 946 \mathrm{~cm}^{-1}\left(\mathrm{v}_{1}\right)$. The bands situated at $3446 \mathrm{~cm}^{-1}$ and $1627 \mathrm{~cm}^{-1}$ were due to the stretching and bending mode of adsorbed water $\left(\mathrm{H}_{2} \mathrm{O}\right)$ molecules. The bond present at $636 \mathrm{~cm}^{-1}$ and $3578 \mathrm{~cm}^{-1}$ could be attributed to the bending and stretching vibration of the hydroxyl $(\mathrm{O}-\mathrm{H})$ group of HAp [37]. The FTIR spectra of the Mn-HAp samples are shown in Figure 4c. The bands appearing at $3442 \mathrm{~cm}^{-1}$ and $1632 \mathrm{~cm}^{-1}$ could be due to the presence of stretching and bending mode of water $\left(\mathrm{H}_{2} \mathrm{O}\right)$ molecules. The main Mn-HAp characteristic $\mathrm{PO}_{4}{ }^{3-}$ peaks were observed at $1086 \mathrm{~cm}^{-1}\left(\mathrm{v}_{3}\right)$, $594 \mathrm{~cm}^{-1}\left(\mathrm{v}_{4}\right), 463 \mathrm{~cm}^{-1}\left(\mathrm{v}_{2}\right)$, and $945 \mathrm{~cm}^{-1}\left(\mathrm{v}_{1}\right)$. The stretching and bending mode of $\mathrm{OH}$ was also seen in the spectrum region 3587 and $636 \mathrm{~cm}^{-1}$. Figure $4 \mathrm{~d}$ shows the Mn-HAp/ZnO bilayer coating on 316L SS. All these peaks confirm the presence of Mn-HAp bilayer coating on 316L SS, and some of 
the $\mathrm{ZnO}$ peaks were present in the spectrum, which strongly confirms that the bilayer coating was present in the substrate.

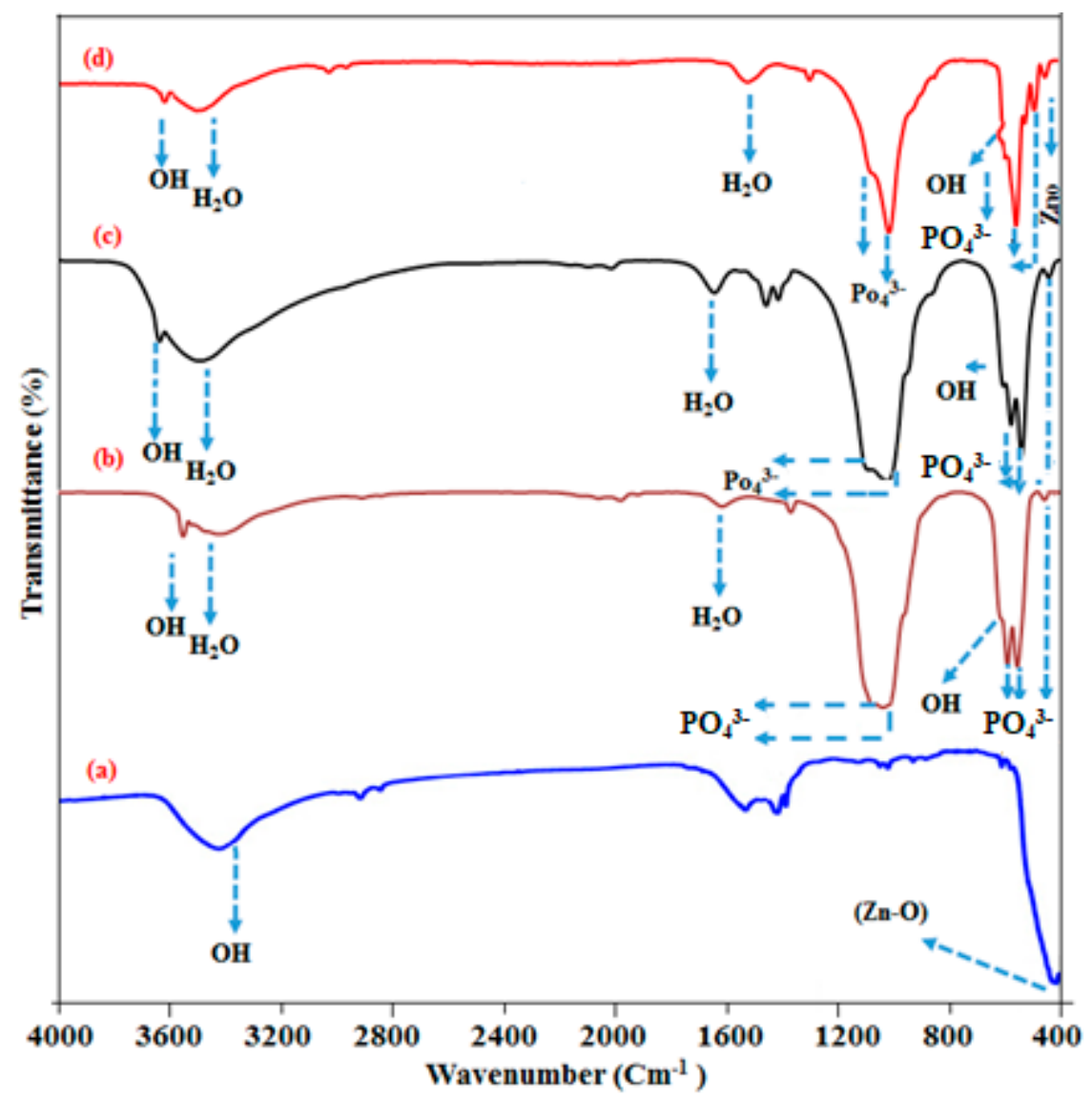

Figure 4. FTIR spectra of (a) ZnO, (b) HAp, (c) Mn-HAp, and (d) Mn-HAp/ZnO bilayer coating on $316 \mathrm{~L}$ SS.

\subsection{X-ray Photoelectron Spectroscopy (XPS) Analysis}

Figure 5a-d shows the surface composition of ZnO, HAp, Mn-HAp, and Mn-HAp/ZnO bilayer coatings. Figure 5a displays the XPS spectra of ZnO coating on 316L SS. The peak positions at 1022.6 and $1043.7 \mathrm{eV}$ resemble the $\mathrm{Zn} 2 \mathrm{p}_{3 / 2}$ and $\mathrm{Zn} 2 \mathrm{p}_{1 / 2}$ core levels, respectively. The asymmetric peak is observed in the $\mathrm{O} 1 \mathrm{~s}$ region for $\mathrm{ZnO}$ coated samples and the corresponding binding energy is $530.2 \mathrm{eV}$ [38]. The peak at $290.4 \mathrm{eV}$ is attributed to C 1s XPS peak. From the XPS spectrum of HAp coating on 316L SS, as shown in Figure 5b, the elemental position of O1s, Ca2 $\mathrm{p}_{1 / 2}, \mathrm{Ca} 2 \mathrm{p}_{3 / 2}$, $\mathrm{P} 2 \mathrm{p}$, and C1s peaks corresponds to the binding energies 534.3, 353.2, 351.3, 135.8, and $237.9 \mathrm{eV}$ [39]. From Figure $6 \mathrm{c}$, it can be concluded that there is no major dissimilarity between HAp and Mn-HAp, except that the Mn ions are incorporated into the HAp crystal structure and the binding energies of $\mathrm{Mn} 2 \mathrm{p}_{1 / 2}$ and $\mathrm{Mn} 2 \mathrm{p}_{3 / 2}$ are 643.3 and $655.6 \mathrm{eV}$, respectively. Figure $5 \mathrm{~d}$ shows the XPS spectrum of Mn-HAp/ZnO bilayer coating on 316L SS. Here most of the Mn-HAp and ZnO peaks are mixed together, with no other impurity peaks, which indicates the strong attachment of Mn-HAp with the bilayer coating on 316L SS. 


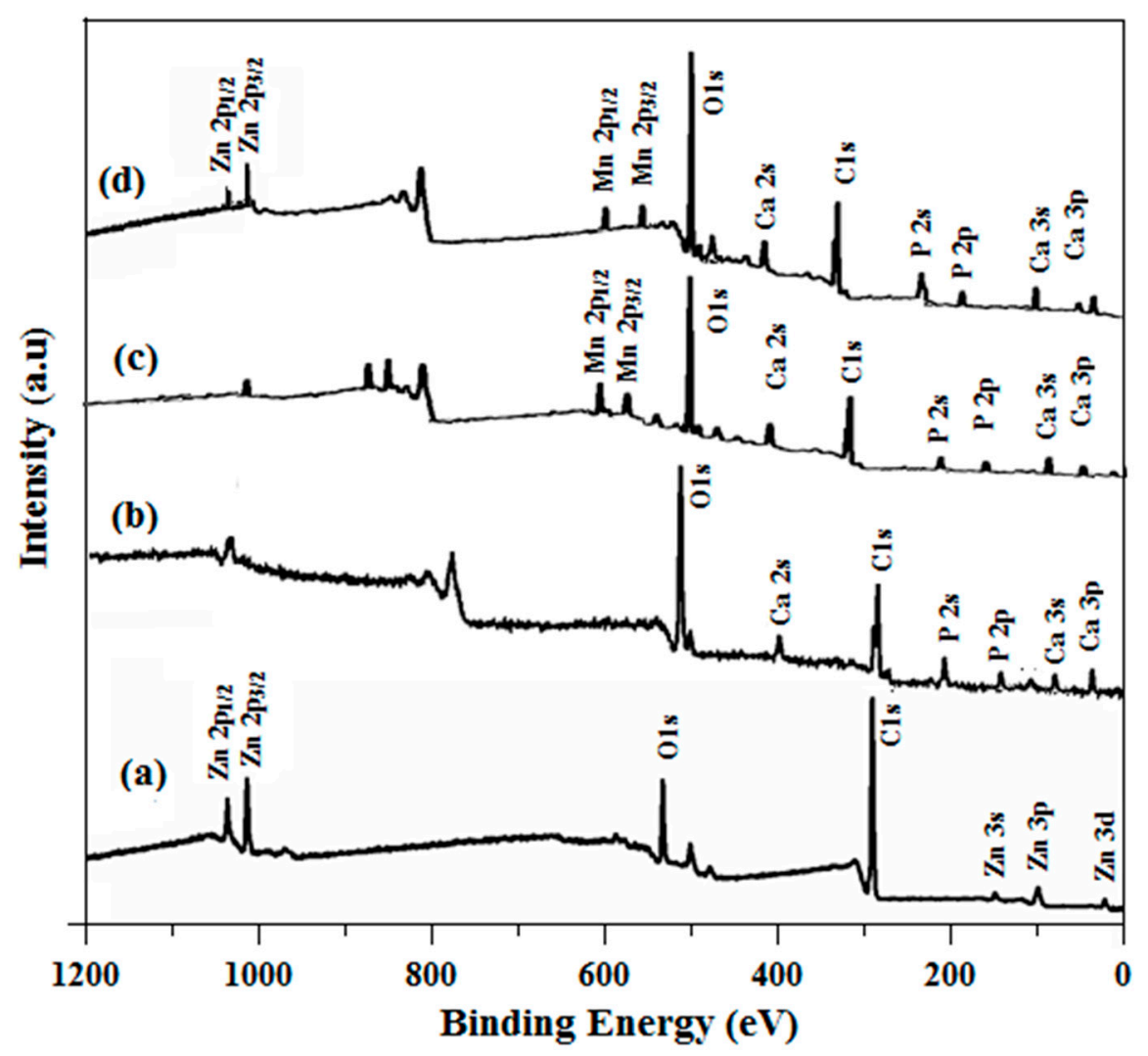

Figure 5. XPS analysis of (a) ZnO, (b) HAp, (c) Mn-HAp, and (d) Mn-HAp/ZnO bilayer coating on 316L SS.

\subsection{Mechanical Characterization}

The mechanical strength analysis is an important parameter for bioimplants, since it gives information about the load-bearing affinity under stress when the device is implanted into the human body. Figure 6a shows the adhesion strength of the HAp, Mn-HAp, $\mathrm{ZnO}$, and Mn-HAp/ZnO bilayer coatings on 316L SS alloy. The adhesion strength of the pristine HAp and $\mathrm{ZnO}$ coating is 8.9 and $13.8 \mathrm{MPa}$, respectively, while the $\mathrm{Mn}-\mathrm{HAp}$ and $\mathrm{Mn}-\mathrm{HAp} / \mathrm{ZnO}$ bilayer coating values are 10.2 and $11.6 \mathrm{MPa}$. The increased adhesion strength of the bilayer coating is due to the unique microstructure of the $\mathrm{ZnO}$-coated 316L SS surface. Figure $6 \mathrm{~b}$ shows the hardness test of the pristine 316L SS and the Mn-HAp, ZnO, and Mn-HAp/ZnO bilayer coating on 316L SS alloy. For the pristine 316L SS and Mn-HAp and ZnO coating, the Vickers microhardness values are found to be $293 \pm 52$, $326.7 \pm 23$ and $96 \pm 24$, respectively. The Hv value (362 \pm 69 ) obtained for the Mn-HAp/ZnO bilayer coating was higher than that of the other samples. The increased mechanical strength was influenced by mechanical interlocking and chemical bonding, which was improved by sintering. The micron-size particle could improve the mechanical strength and very long-term functionality of the coating [40]. This improved adhesion strength and hardness of the as-formed Mn-HAp/ZnO bilayer coating on 316L SS substrate, making it suitable for biomedical applications. 

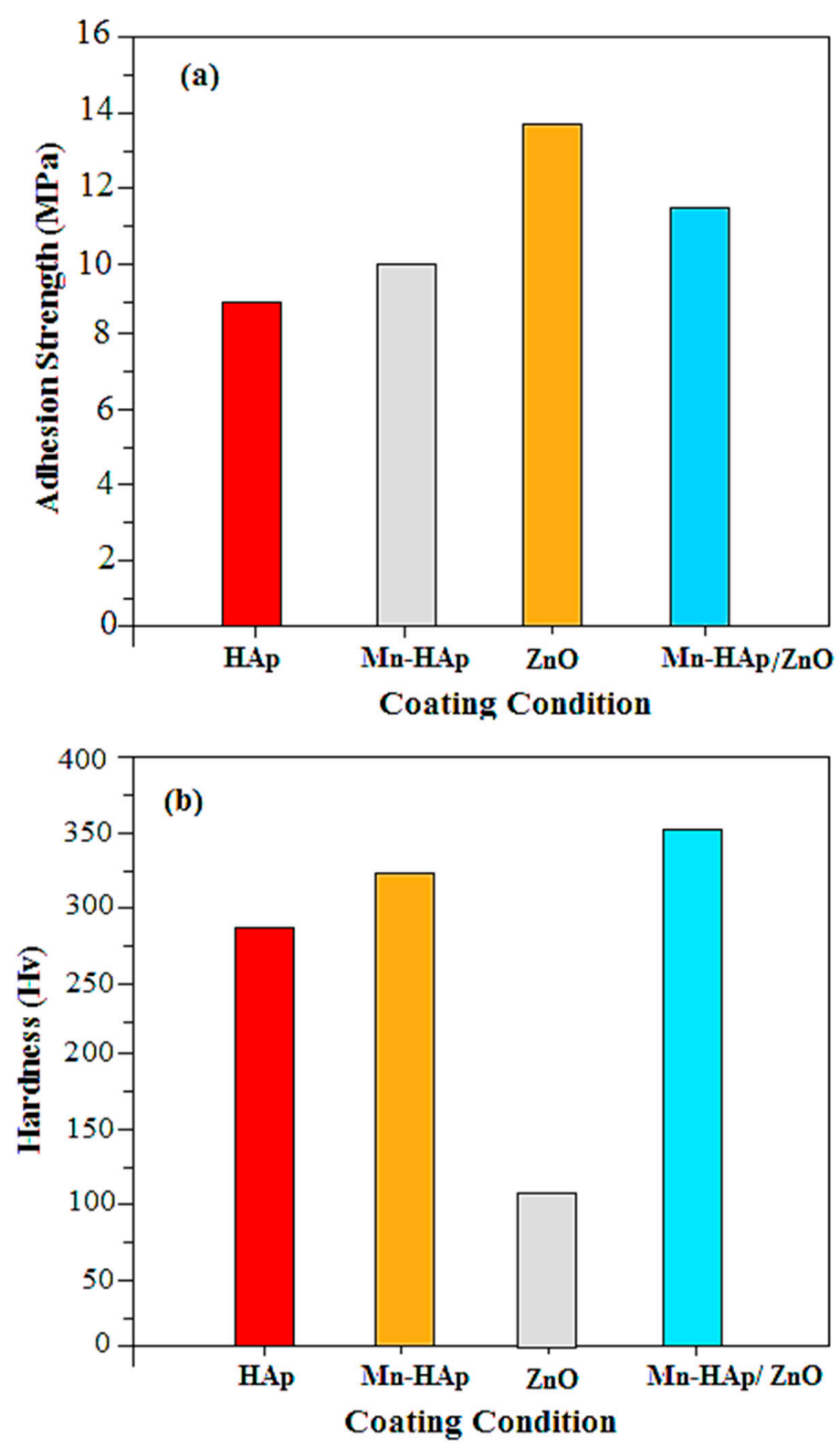

Figure 6. (a) Adhesion strength; (b) hardness strength of HAp, Mn-HAp, ZnO and Mn-HAp/ZnO bilayer coating on 316L SS.

\subsection{Electrochemical Characterization of Coating}

\subsubsection{Potentiodynamic Polarization Measurements}

The potentiodynamic cyclic polarization curves of pristine 316L SS, and Mn-HAp, ZnO and Mn-HAp/ZnO bilayer coatings on 316L SS in SBF solution were recorded in the potential range of $-1.0 \mathrm{~V}$ to $0.9 \mathrm{~V}$ in order to study the passivation and breakdown behavior of both coating types, and are shown in Figure 7 . The corrosion potential ( $\left.\mathrm{E}_{\mathrm{corr}}\right)$, breakdown potential $\left(\mathrm{E}_{\mathrm{b}}\right)$, and repassivation potential $\left(\mathrm{E}_{\mathrm{pp}}\right)$ curves of the samples were determined from the polarization curve values presented in Table 1. The polarization plots of the Mn-HAp, $\mathrm{ZnO}$ and $\mathrm{Mn}-\mathrm{HAp} / \mathrm{ZnO}$ bilayer coatings on 316L SS samples showed a significant shift toward the nobler direction compared to the pristine 316L SS sample. Polarization curves showed that the $E_{c o r r}, E_{b}$ and $E_{p p}$ values for the pristine 316L SS alloy were $-874 \mathrm{mV},+348 \mathrm{mV}$ and $-75 \mathrm{mV}$ vs. saturated calomel electrode (SCE), respectively. The polarization curve recorded for Mn-HAp coated 316LSS alloy showed $E_{c o r r}, E_{b}$ and $E_{p p}$ values of 
$-832 \mathrm{mV},+410 \mathrm{mV}$ and $-48 \mathrm{mV}$ vs. SCE, respectively. The polarization curve of $\mathrm{ZnO}$ coated 316L SS alloy showed $E_{c o r r}, E_{b}$ and $E_{p p}$ values of $-781 \mathrm{mV},+486 \mathrm{mV}$ and $26 \mathrm{mV}$ vs. SCE, respectively. The shift in $E_{c o r r}, E_{b}$ and $E_{p p}$ values toward the noble direction is an indication that Mn-HAp/ZnO bilayer coating on 316L SS alloy has high corrosion protection in SBF solution. The $\mathrm{E}_{\mathrm{corr}}, \mathrm{E}_{\mathrm{b}}$ and $\mathrm{E}_{\mathrm{pp}}$ values for the pristine 316L SS alloy were $-696 \mathrm{mV},+574 \mathrm{mV}$ and $-92 \mathrm{mV}$ vs. SCE, respectively. The $\mathrm{ZnO}$ coating layer offers corrosion protection of metallic substrates by acting as a barrier against electron and ion diffusion, thus dropping the electrochemical reactions at the interface of 316L SS and electrolyte. It also forms a densely filled and crack-free coating. This coating acts as a barrier between the uncoated surface and the SBF solution, enhancing corrosion protection when associated with the individual coating [41].

Table 1. Potentiodynamic polarization parameters of pristine 316L SS, and Mn-HAp, ZnO, and Mn-HAp/ZnO bilayer coating on 316L SS. SCE, saturated calomel electrode.

\begin{tabular}{ccccc}
\hline \multicolumn{5}{c}{ Polarization Parameter } \\
\hline Sample Condition & $\mathbf{E}_{\mathbf{c o r r}}(\mathbf{m V}$ vs. SCE) & $\mathbf{E}_{\mathbf{b}}(\mathbf{m V})$ & $\mathbf{E}_{\mathbf{p p}}(\mathbf{m V})$ & $\mathbf{R}_{\mathbf{b}}\left(\mathbf{\Omega} / \mathbf{c m}^{\mathbf{2}}\right)$ \\
\hline Pristine 316L SS & -874 & 348 & -75 & 48 \\
Mn-HAp & -832 & 410 & -48 & 1200 \\
ZnO & -781 & 486 & -26 & 2980 \\
Mn-HAp/ZnO & -696 & 574 & -92 & 3400 \\
\hline
\end{tabular}

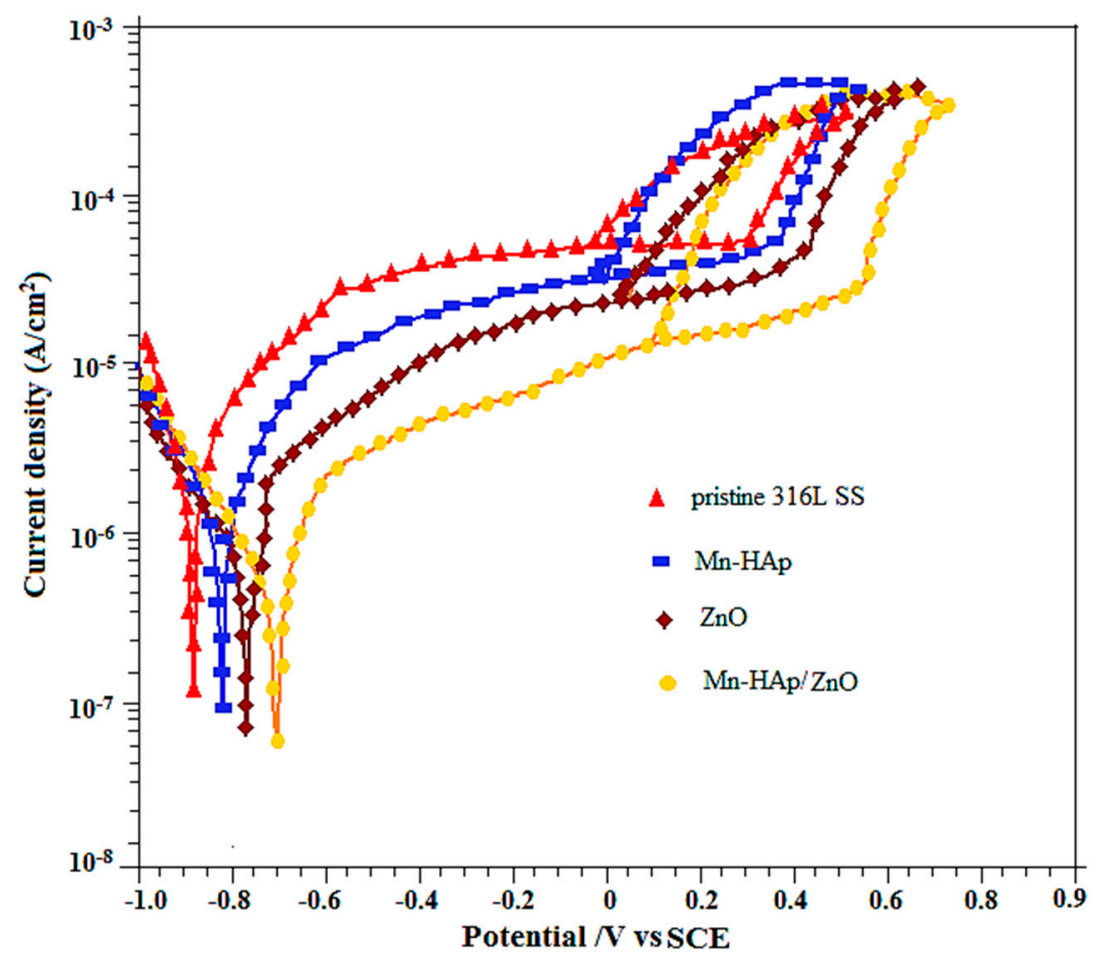

Figure 7. Potentiodynamic cyclic polarization curves of pristine 316L SS, and Mn-HAp, ZnO, and Mn-HAp/ZnO bilayer coating on 316L SS in simulated body fluid (SBF) solution.

\subsubsection{Electrochemical Impedance Spectroscopy (EIS) Analysis}

An extended electrochemical study was conducted on 316L SS with protective Mn-HAp/ZnO coatings in order to follow its corrosion performance in SBF solution for long-term implant applications. EIS spectra were analyzed with an equivalent circuit and curve fitting was performed for all substrates, showing excellent agreement between the experiments and the fitting. The impedance spectra obtained for pristine, $\mathrm{ZnO}$ coated, and $\mathrm{Mn}-\mathrm{HAp} / \mathrm{ZnO}$ coated 316 LS specimens were fitted using an equivalent 
circuit model, as shown in Figure 8a. The fitted equivalent circuit model, denoted as $R_{s}\left(R_{1} C_{d 1}\right)$ $\left(\mathrm{R}_{2} \mathrm{C}_{\mathrm{dl}}\right)$ in Figure 8a, consists of two combinations of resistors and capacitors in series with the solution resistance, used to obtain the spectrum for $\mathrm{ZnO}$ coated 316L SS substrate. $\mathrm{R}_{\mathrm{S}}$ represents the solution resistance or ohmic resistance of the system.
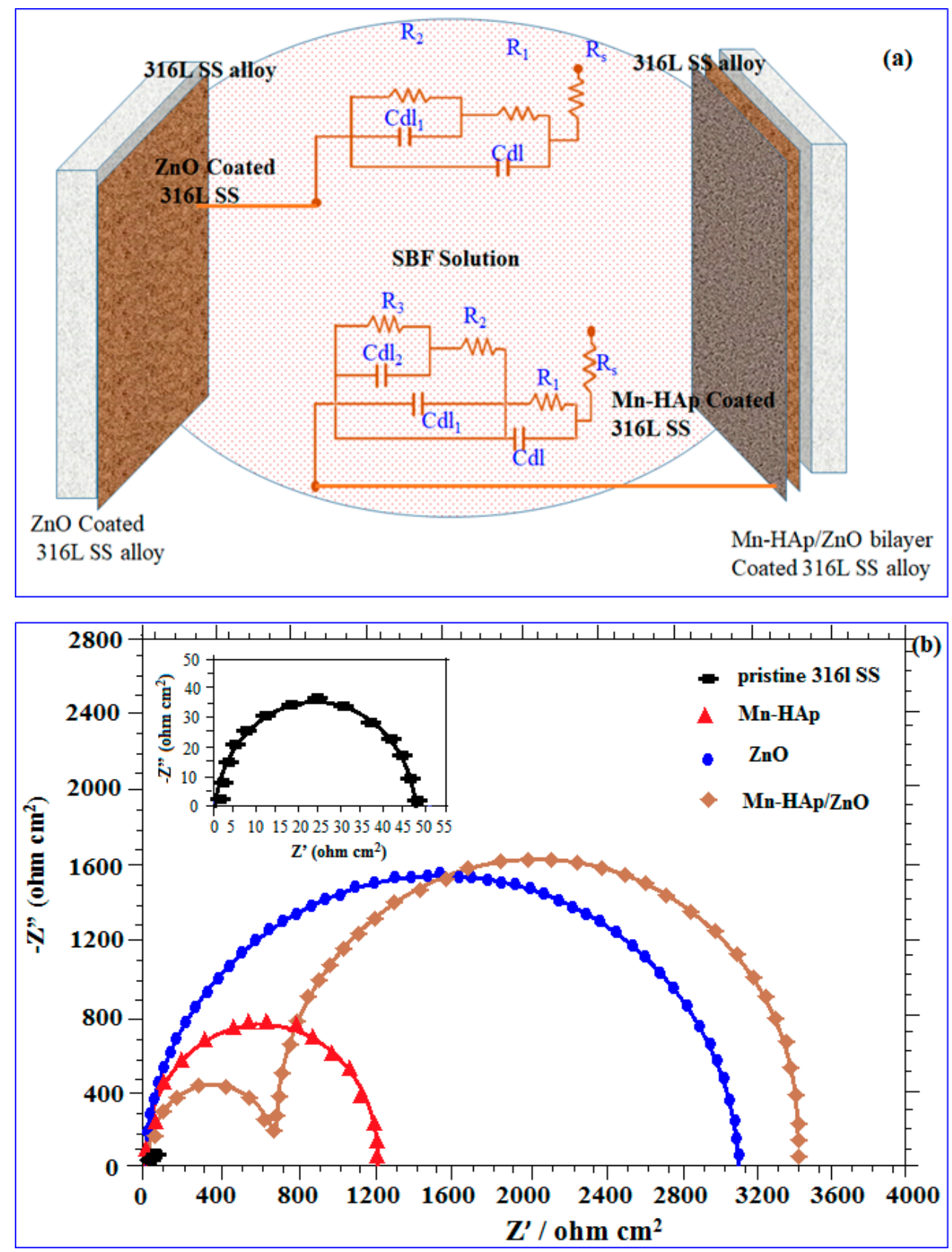

Figure 8. Equivalent circuit obtained for (a) ZnO coated and Mn-HAp/ZnO bilayer coated 316L SS; (b) potentiodynamic Nyquist plot analysis of pristine 316L SS, and Mn-HAp, ZnO, and Mn-HAp/ZnO bilayer coated 316L SS in SBF solution. $C_{d l}$ represents the first layer capacitance and $R_{1}$ represents resistance to the charge transfer of oxidation for uncoated 316L SS. $R_{2}$ and $C_{\mathrm{dl1}}$ represent resistance and capacitance of the $\mathrm{ZnO}$ layer, respectively.

Figure 8a displays the equivalent circuit used to fit the spectrum attained for $\mathrm{Mn}-\mathrm{HAp} / \mathrm{ZnO}$ bilayer coating on 316L SS substrate containing the three combinations of resistor and capacitor in series with solution resistance, represented as $\left(R_{2} C_{d 11}\right)\left(R_{3} C_{d 12}\right)$, where $R_{3}$ and $C_{d 12}$ are resistance 
and capacitance, respectively. This indicates the presence of two time constants, corresponding to the inner $\mathrm{ZnO}$ layer and top Mn-HAp layer. A very large $\mathrm{R}_{\mathrm{p}}$ is related to a slower rusting system. Moreover, superior corrosion protection delivered by an inhibitor is linked with a reduction in $\mathrm{C}_{\mathrm{dl}}$ [42]. The reduction in $\mathrm{C}_{\mathrm{dl}}$, results from a decrease in local dielectric constant and/or an increase in the thickness of the electrical double layer [43].

The electrochemical impedance spectra in the form of Nyquist plots for the pristine 316L SS, and Mn-HAp, ZnO, and Mn-HAp/ZnO bilayer coating on 316L SS in SBF solution under open circuit potential (OCP) conditions is shown in Figure $8 \mathrm{~b}$. The polarization resistance $\left(\mathrm{R}_{\mathrm{b}}\right)$ value for the pristine, Mn-HAp, and $\mathrm{ZnO}$ coated 316L SS was 48, 1200 and $2980 \Omega / \mathrm{cm}^{2}$, respectively. The maximum $R_{b} 3400 \Omega / \mathrm{cm}^{2}$ value was obtained for Mn-HAp/ZnO bilayer coating, showing more corrosion protection than other samples. Two capacitive semicircles were obtained for the $\mathrm{Mn}-\mathrm{HAp} / \mathrm{ZnO}$ bilayer coating; the first, at higher frequencies, can be attributed to the $\mathrm{ZnO}$ layer and the second, at low frequencies, is attributed to the compact Mn-HAp layer. This result is typically witnessed for bilayer coatings containing a dense interior (bottom) layer and a less compact (porous) exterior layer. Considering this, an equivalent circuit was created to simulate the results. In all spectra, the entire value of the maximum phase angle was less than $90^{\circ}$ [44]. From these results, enhancement of the corrosion protection of the bilayer coating is most suitable for implant applications.

\subsection{In Vitro Bioactivity}

Figure 9a shows FESEM images of the apatite formation of Mn-HAp/ZnO bilayer coating on 316L SS after immersing in SBF for 7, 14, 21 and 28 days. After 7 days, a single layer of spherical particles started to deposit on the surface. After 14 days, apatite deposition was rapidly enriched, and after 21 days the surface was covered with particles. Increasing surface nonuniformity was seen due to the increasing Ca-P depositions on the surface. With a further increase in soaking time of 28 days, minor clusters of apatite were detected completely covering the bilayer coating. During the incubation period, calcium (Ca) ions from SBF were attracted by $\mathrm{OH}^{-}$and the exchange of $\mathrm{Ca}^{2+}$ and $\mathrm{H}^{+}$with $\mathrm{OH}^{-}$ resulted in higher $\mathrm{pH}$. Accumulation of $\mathrm{OH}^{-}$on the surface is necessary for apatite nucleation [45]. As $\mathrm{Ca}$ and phosphate $(\mathrm{P})$ ion concentrations reached their maximum, $\mathrm{pH}$ also increased. Ca and $\mathrm{P}$ ions are consumed largely due to the formation of abundant apatite. Since there is a corresponding consumption of $\mathrm{OH}^{-}$, the $\mathrm{pH}$ of SBF decreases. When the equilibrium of dissolution and precipitation is achieved, $\mathrm{pH}$ becomes constant. Normally HAp dissolution occurs in five steps as follows:

$$
\begin{gathered}
\mathrm{Ca}_{5}\left(\mathrm{PO}_{4}\right)_{3} \mathrm{OH}_{(\mathrm{s})}+\mathrm{H}^{+}{ }_{(\mathrm{aq})} \rightleftarrows \mathrm{Ca}_{5}\left(\mathrm{PO}_{4}\right)_{3}\left(\mathrm{H}_{2} \mathrm{O}\right)^{+}{ }_{(\mathrm{s})} \\
2 \mathrm{Ca}_{5}\left(\mathrm{PO}_{4}\right)_{3}\left(\mathrm{H}_{2} \mathrm{O}\right)^{+}{ }_{(\mathrm{s})} \rightleftarrows 3 \mathrm{Ca}_{3}\left(\mathrm{PO}_{4}\right)_{2(\mathrm{~s})}+\mathrm{Ca}^{2+}{ }_{(\mathrm{aq})}+2 \mathrm{H}_{2} \mathrm{O} \\
\mathrm{Ca}_{3}\left(\mathrm{PO}_{4}\right)_{2(\mathrm{~s})}+2 \mathrm{H}^{+}{ }_{(\mathrm{aq})} \rightleftarrows \mathrm{Ca}^{2+}{ }_{(\mathrm{aq})}+2 \mathrm{CaHPO}_{4(\mathrm{~s})} \\
\mathrm{CaHPO}_{4(\mathrm{~s})}+\mathrm{H}^{+}{ }_{(\mathrm{aq})} \rightleftarrows \mathrm{Ca}^{2+}{ }_{(\mathrm{aq})}+\mathrm{H}_{2} \mathrm{PO}_{4(\mathrm{aq})}^{-} \\
\mathrm{CaHPO}_{4(\mathrm{~s})} \rightleftarrows \mathrm{Ca}^{2+}{ }_{(\mathrm{aq})}+\mathrm{HPO}_{4(\mathrm{aq})}^{2-}
\end{gathered}
$$


(a)

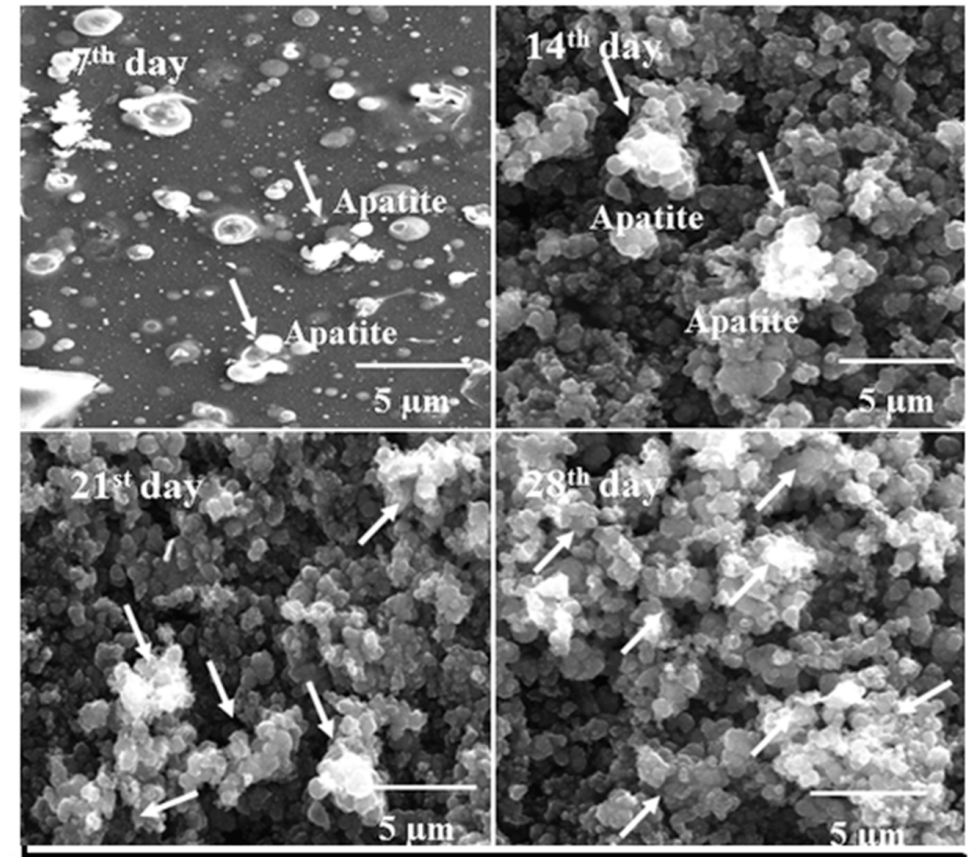

(b)
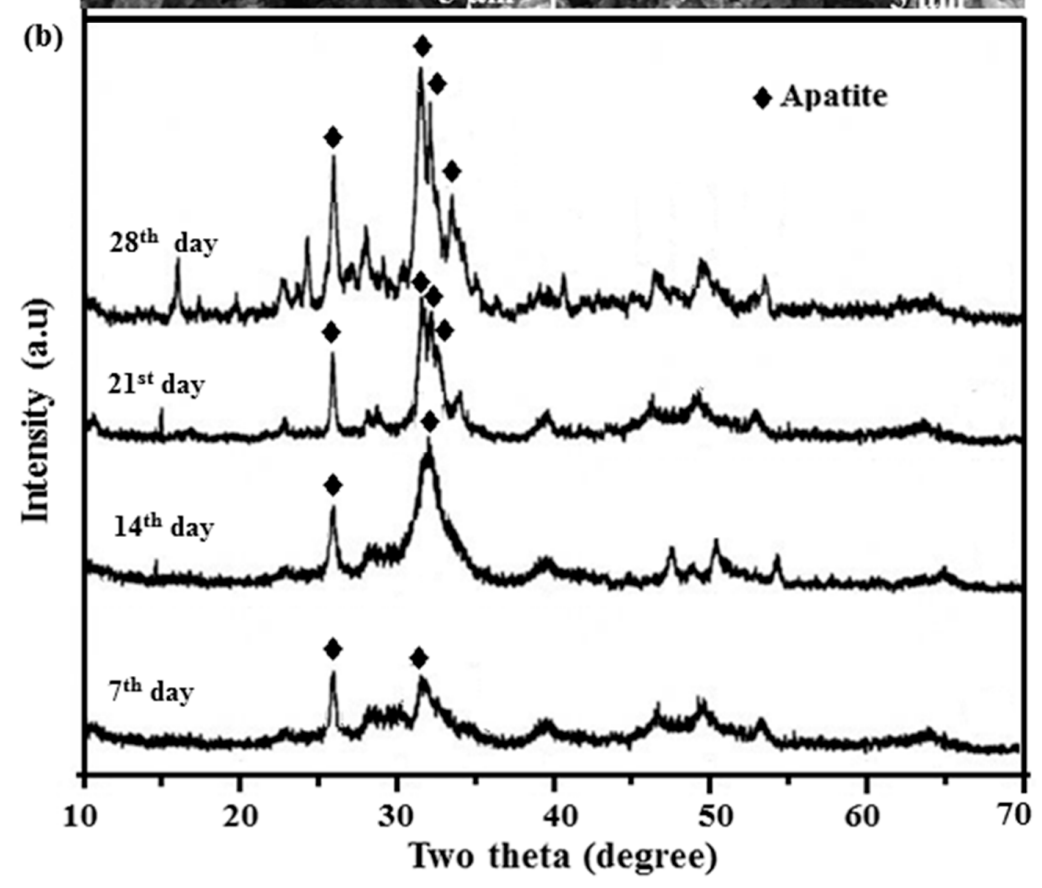

Figure 9. (a) FESEM images and (b) XRD pattern of Mn-HAp/ZnO bilayer coating on 316L SS at 7, 14, 21 and 28 days of incubation in SBF solution.

Figure $9 \mathrm{~b}$ shows the apatite formation ability of Mn-HAp/ZnO bilayer coating on 316L SS samples soaked in SBF solution at 7, 14, 21 and 28 days. Two low-intensity apatite peaks $2 \theta=26.14^{\circ}$ and another peak between $31.24^{\circ}$ and $33.06^{\circ}$ were first observed at 7 days of immersion, with the wide-ranging apatite peaks designated low crystallinity of apatite formed in vitro at this initial stage of soaking. The HAp triplet peak and $\mathrm{ZnO}$ peaks appeared in the Mn-HAp/ZnO bilayer coating before immersion in SBF (Figure 3d). Now the peaks were suppressed at 7 and 14 days of incubation (Figure 9b), suggesting that surface chemistry processes were occurring in the samples. The intensity of apatite peaks increased gradually with immersion time, indicating the growth of an apatite layer on the composite surface in SBF, and another two peaks at $33.02^{\circ}$ and $35.14^{\circ}$ appeared after 14 and 28 days 
of immersion. The rapid increase of apatite peak intensity indicates more biomineralization ability in the present coating.

\subsection{Inductively Coupled Plasma Atomic Emission Spectrometry (ICP-AES) Analysis}

Potentiodynamic polarization tests were performed at a constant potential of $0.45 \mathrm{mV}$ vs. SCE after aging of $1 \mathrm{~h}$ to determine the concentration of metal atoms, namely chromium $(\mathrm{Cr})$, nickel (Ni), molybdenum (Mo), and iron (Fe), which are leached out from the 316L SS during the corrosion process. These results specify the resistance of the alloys to the toxic metal ions, which produce local systemic effects and thereby play a crucial role in prosthetic loosening. The rate of surface dissolution can be identified by monitoring the evolution of ions from the implant material into the solution. Figure 10 shows the concentration of leached out metal ions from the pristine 316L SS, and Mn-HAp, ZnO, and Mn-HAp/ZnO bilayer coating on 316L SS. A substantial amount of $\mathrm{Fe}, \mathrm{Cr}, \mathrm{Ni}$, and $\mathrm{Mo}$ atoms were leached out from the pristine 316L SS [46]. This indicates that no barrier film on the 316L SS surface prevents the attack of chloride ions in the SBF solution. However, the rate of dissolution of ions has little control on Mn-HAp coated on 316L SS, only a considerable amount of manganese and phosphate are released from the coated substrate. The $\mathrm{ZnO}$ coating on 316L SS substrate exposes the amount of leached out metal ions, which was lower than that of the pristine 316L SS and Mn-HAp coating. Furthermore, the leach-out is extremely reduced in Mn-HAp/ZnO bilayer coating and it prevents the unwanted metal ions from going into the body. Hence the prepared bilayer coating is highly suitable for bioimplants.

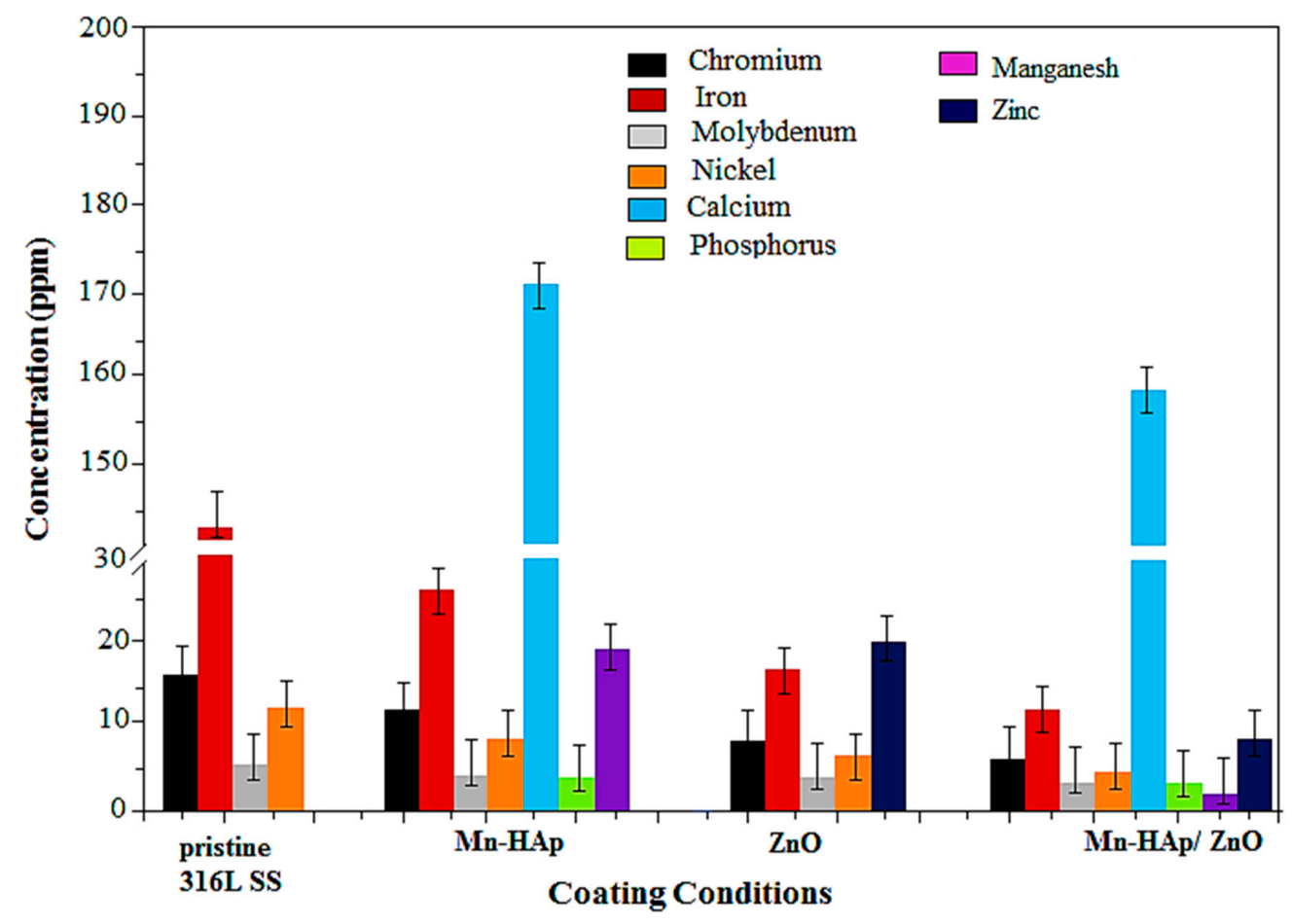

Figure 10. Leach-out analysis of pristine 316L SS, and Mn-HAp, ZnO, and Mn-HAp/ZnO bilayer coating on 316L SS. [The \% error of the measured sample associated to the true value is determined by the following equation: $\%$ error $=$ Absolute value [(true value-measured value) $/$ true value $\times 100$. Acceptance criteria is a \%RD and a \% Error less than $10 \%$.]. 


\subsection{In Vitro Biocompatibility Cell Culture Studies}

\subsubsection{Cell Viability}

The enhanced cell viability of the bilayer coating is mainly due to the presence of porous Mn-HAp coating on $\mathrm{ZnO}$ coated 316L SS. Cell viability of $125 \mu \mathrm{g} \mathrm{mL}-1$ of $\mathrm{Mn}-\mathrm{HAp}, \mathrm{ZnO}$, and Mn-HAp/ZnO bilayer coating on 316L SS substrates at 3,7, 14, 21 days of culture is shown in Figure 11. Cell viability in the coated samples was studied using the MTT (3-(4,5-dimethylthiazol-2-yl)-2,5-diphenyl tetrazoliumbromide) assay, which is a measure of the mitochondrial activity in cells. The results show that cell viability of the bilayer coating $(85 \%, 95 \%, 102 \%$ and $108 \%)$ increased extensively compared to the Mn-HAp coating (73\%, 81\%, $84 \%$ and $87 \%$ ) and $\mathrm{ZnO}$ coating $(82 \%, 89 \%, 92 \%$ and $96 \%)$ at $3,7,14$ and 21 days of culture, respectively. Statistical analysis was carried out on cellular tests using one-way analysis of variance (ANOVA) at an average of 3-5 replicates. Differences were considered statistically significant at $p<0.05$. These results suggest that the bilayer coating shows the best cell viability and so is highly suited for biomedical applications.

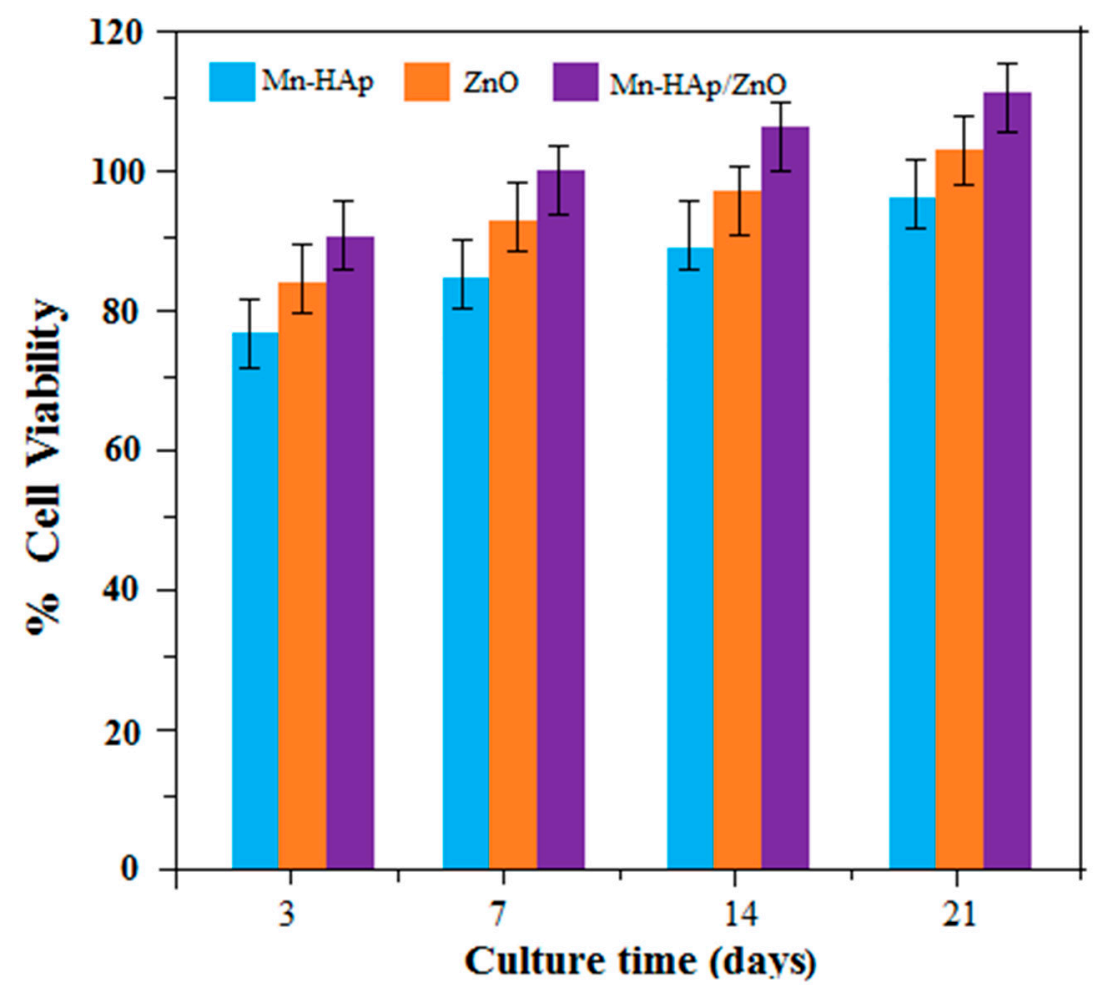

Figure 11. Cell viability of Mn-HAp, ZnO, and Mn-HAp/ZnO bilayer coating on 316L SS.

\subsubsection{Cell Adhesion}

Adhesion strength is an important property for in vivo implantation. Here the adhesion strength of Mn-HAp/ZnO bilayer coating on 316L SS alloy was evaluated at 3, 7, 14 and 21 days. After 3 and 7 days of culture, the cells were attached on the surfaces and exhibited a heterogeneous morphology spreading on the substrate (Figure 12a,b). Calcium and phosphorous are also vital in improving osteoblastic cell behavior and in vivo bone regeneration. $\mathrm{Ca}^{2+}$ has a crucial role in bone regeneration and controls the proliferation and differentiation of target osteoblasts [47]. After 14 days of culture, the osteoblast cells were elongated with only limited areas of spreading at the ends of long filopodia structures, as shown in Figure 12c. Finally, after 21 days of culture, there were cell-to-cell contacts and polygonal or bipolar morphology with extensions in various directions on the surface coatings, shown in Figure 12d. The porous structured layer of bilayer coating offers enhanced bioactivity due to surface roughness, which leads to increased surface energy [48]. 

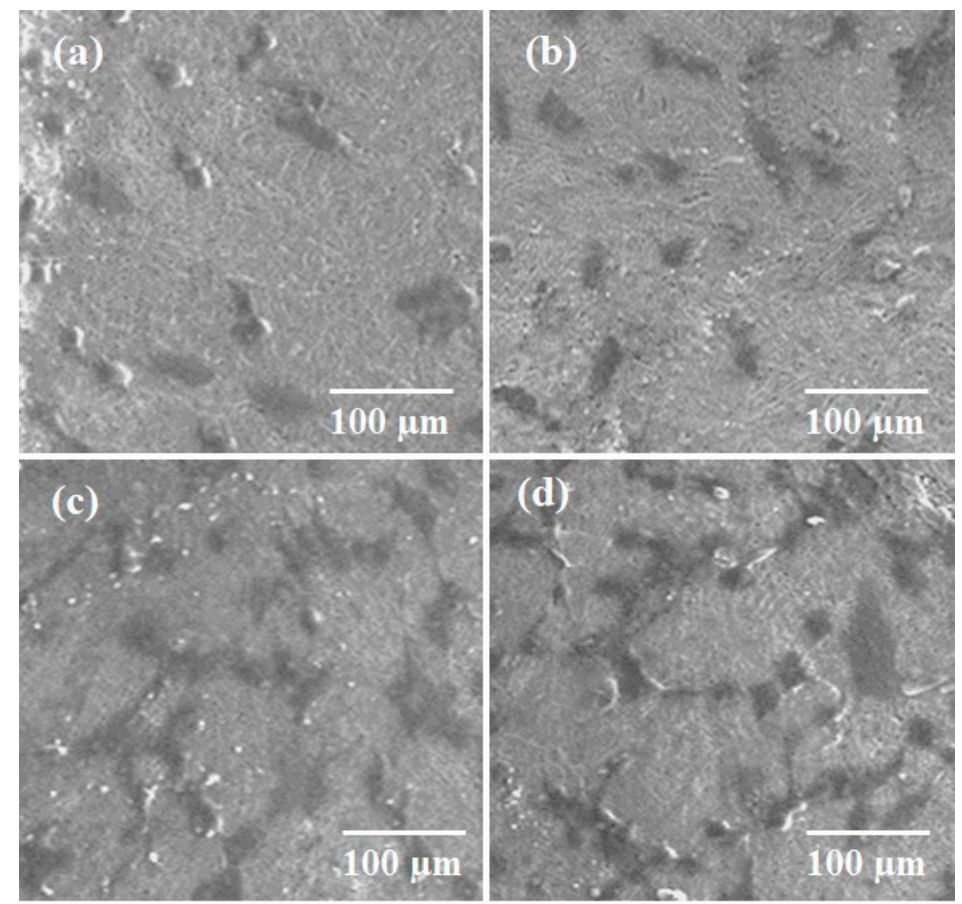

Figure 12. (a-d) FESEM images of MG-63 osteoblast cell proliferation of Mn-HAp/ZnO bilayer coating on 316L SS substrate at (a) 3, (b) 7, (c) 14 and (d) 21 days.

\subsubsection{Live/Dead Assay}

Cytocompatibility analysis of Mn-HAp, ZnO, and Mn-HAp/ZnO bilayer coating on 316L SS was performed to assess live/dead staining, depicted in Figure 13. In the images of live/dead staining, viable cells are shown in green and dead cells in red. Visual inspection readily shows sustained attachment of the coatings and growth of specific osteoblast cell types, supporting the overall biocompatibility of the coatings. All the groups showed increased cell proliferation on the fifth day when compared to the first day. Figure 13c,f shows the live/dead staining of Mn-HAp/ZnO bilayer coating, which had the least dead cells and most living cells compared to Mn-HAp (Figure 13a,d) and $\mathrm{ZnO}$ (Figure 13b,e). The results of the live/dead assay show that most MG63 cells on all 316 LSS substrates were live (green) except one or two dead cells (red), so these coatings are safe and appropriate for the growth of osteoblasts. The results of the cell culture experiments confirm that the bilayer coating on 316L SS plays a vital role in implant applications. 


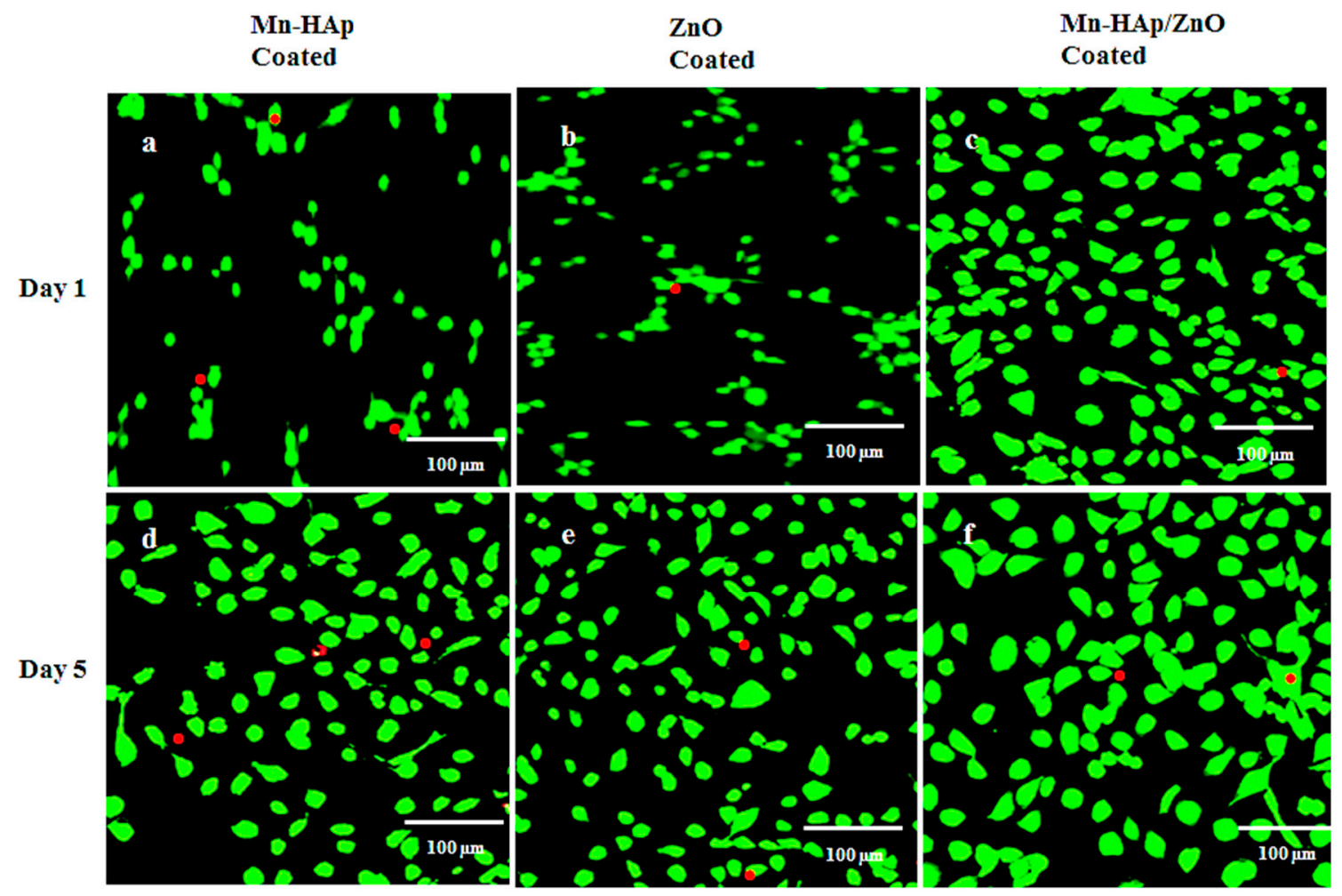

Figure 13. (a-f) Live/dead cell analysis of (a,d) Mn-HAp, (b,e) ZnO, and (c,f) Mn-HAp/ZnO bilayer coating on 316L SS at 1 and 5 days of culture. Red color-dead cells, Green Color-Live Cells.

\section{Materials and Methods}

\subsection{Materials}

Zinc nitrate hexahydrate $\left(\mathrm{Zn}\left(\mathrm{NO}_{3}\right)_{2} \cdot 6 \mathrm{H}_{2} \mathrm{O}\right)$, calcium nitrate tetrahydrate $\left(\mathrm{Ca}\left(\mathrm{NO}_{3}\right)_{2} \cdot 4 \mathrm{H}_{2} \mathrm{O}\right)$, diammonium hydrogen phosphate $\left(\mathrm{NH}_{4}\right)_{2} \mathrm{HPO}_{4}$, manganese nitrate tetrahydrate $\left(\mathrm{Mn}\left(\mathrm{NO}_{3}\right)_{2} \cdot 4 \mathrm{H}_{2} \mathrm{O}\right)$, ethanol $(\mathrm{EtOH})$, and ammonium hydroxide $\left(\mathrm{NH}_{4} \mathrm{OH}\right)$ were purchased from Sigma Aldrich Chemical \& Co. (Tamil Nadu, India). All the chemicals were of analytical grade, and deionized water was used throughout the experiment.

\section{2. $\mathrm{ZnO}$ Coating on $316 \mathrm{~L} S \mathrm{~S}$}

A conventional cell with a 3-electrode configuration was used for electrochemical deposition, by using an electrochemical workstation (CHI 760C, CH Instruments, Austin, TX, USA) in which platinum electrode was used as the counterelectrode, 316L SS alloy as the working electrode, and saturated calomel electrode (SCE) as the reference electrode. The electrolyte was prepared by dissolving $0.1 \mathrm{M} \mathrm{Zn}\left(\mathrm{NO}_{3}\right)_{2} \cdot 6 \mathrm{H}_{2} \mathrm{O}$ into $100 \mathrm{~mL}$ of absolute ethanol in a sealed container and stirring continuously for $30 \mathrm{~min}$ at room temperature to form a transparent solution, which acted as a precursor [49]. Electrodeposition of $\mathrm{ZnO}$ was carried out at room temperature and at a current density of $0.75 \mathrm{~mA} \cdot \mathrm{cm}^{-2}$ for $60 \mathrm{~min}$. After the deposition of $\mathrm{ZnO}$, the coated 316L SS surface was washed with deionized water to remove residual electrolyte, and after that the coated samples were naturally dried for $24 \mathrm{~h}$.

\subsection{Mn-HAp Coating on $316 L$ SS}

Mn-HAp deposition on 316L SS was carried out in an aqueous solution containing $0.5 \mathrm{M}$ $\left(\mathrm{Ca}\left(\mathrm{NO}_{3}\right)_{2} \cdot 4 \mathrm{H}_{2} \mathrm{O}\right), 0.03 \mathrm{M}\left(\mathrm{NH}_{4}\right)_{2} \cdot \mathrm{HPO}_{4}$ and $0.003 \mathrm{M}\left(\mathrm{Mn}\left(\mathrm{NO}_{3}\right)_{2} \cdot 4 \mathrm{H}_{2} \mathrm{O}\right)$ under magnetic stirring at room temperature with the following parameters: $\mathrm{pH} 4.5$, current density $9 \mathrm{~mA} / \mathrm{cm}^{2}$, and duration 
$30 \mathrm{~min}$ [50]. The coated substrate was gently rinsed with deionized water and then dried at room temperature for $24 \mathrm{~h}$.

\subsection{Mn-HAp/ZnO Bilayer Coating on 316L SS}

Mn-HAp was coated galvanostatically on the $\mathrm{ZnO}$ coated 316L SS at a constant current density of $9 \mathrm{~mA} / \mathrm{cm}^{2}$ for a duration of $30 \mathrm{~min}$. After deposition of the Mn-HAp/ZnO bilayer coating on 316L SS surface, it was washed with deionized water to remove residual electrolyte and dried for $24 \mathrm{~h}$. All potentials in this experiment are quoted on the SCE scale.

\subsection{Surface Characterization of Coating}

The functional group analysis of coating samples was characterized by Fourier transform infrared spectroscopy (FTIR) using a Nicolet 8600 FTIR spectrometer (Tamil Nadu, India). FTIR spectra were recorded from 400 to $4000 \mathrm{~cm}^{-1}$ with $4 \mathrm{~cm}^{-1}$ resolution, averaging 100 scans. The phase composition of the coatings was analyzed by X-ray diffraction (XRD) using a Bruker D8 Advanced diffractometer (Karlsruhe, Germany) with $\mathrm{Cu}-\mathrm{K} \alpha$ radiation, $40 \mathrm{kV} / 40 \mathrm{~mA}$, and $\lambda=1.5406 \mathrm{~nm}$. The surface morphology of coating specimens was studied by field emission scanning electron microscopy (FESEM; Quanta 250 FEG, FEI Company, (Hillsboro, OR, USA) at $30 \mathrm{kV}$. Energy dispersive X-ray Analysis (X Flash Detector, 5030 Bruker Nano, Karlsruhe, Germany) examined the elemental compositions of all coated specimen. The elemental compositions of the present samples were determined by X-ray photoemission spectroscopy (XPS) with a VGS ESCALAB 210 instrument (Oakville, ON, Canada). The inner surface morphology of coatings was obtained by transmission electron microscopy (TEM; JEOL JEM2010, 200 Kv, Pleasanton, CA, USA) and HRTEM (JEM-2100F, Williamston, SC, USA).

\subsection{Mechanical Properties of Coatings}

The mechanical properties of the coatings were analyzed using a Universal Instron Mechanical Testing system (Instron 5565, Instron Co., Norwood, MA, USA) according to ASTM F 1044-05 standards [51], assessing the adhesion strength between HAp, Mn-HAp, ZnO, and Mn-HAp/ZnO bilayer coatings on 316 LS specimens. Adhesion strength is an essential property for in vivo implantation. Six parallel score lines were made $1.0 \mathrm{~mm}$ apart; an additional 6 score lines were inscribed vertical to the original lines. For each distinct specimen, 25 grids were produced. Adhesive tape was placed on the grids using a soft eraser; the tape was then detached with a firm and stable pulling action. Hardness of the coatings was determined using Akashi AAV-500 series hardness tester (Kanagawa, Japan). The loading force of $50 \mathrm{~g}$ for a duration of $5 \mathrm{~s}$ and the hardness measurement were carried out 10 times for coated and uncoated substrates.

\subsection{Inductively Coupled Plasma Atomic Emission Spectrometry (ICP-AES)}

The leached out metal ions from pristine 316L SS, and Mn-HAp, ZnO, and Mn-HAp/ZnO bilayer coating on 316L SS substrate were determined by applying an impressed potential of $455 \mathrm{mv}$ vs. SCE just above the breakdown potential $\left(E_{b}\right)$ of the pristine 316L SS for $1 \mathrm{~h}$ in SBF solution after completion of the potentiodynamic polarization analysis. At the end of each experiment an aliquot of $10 \mathrm{~mL}$ of medium was collected for ICP-AES analysis (Thermo Jarrel-Ash Atom scan, Franklin, MA, USA).

\subsection{Electrochemical Investigation of Coatings}

Corrosion performance of pristine 316L SS, and Mn-HAp, ZnO, and Mn-HAp/ZnO bilayer coating on 316L SS alloy was analyzed by potentiodynamic polarization and electrochemical impedance spectroscopy (EIS) in SBF solution. $\mathrm{pH}$ and temperature were maintained at 7.4 and $37^{\circ} \mathrm{C}$, respectively. All electrochemical measurements were carried out using the 3 electrode electrochemical workstation with CHI 760 (Austin, TX, USA), The saturated calomel electrode (SCE) and platinum electrode were taken as the reference and counterelectrode, respectively, and coated 316L SS as a working electrode was 
used for all measurements. All potential values are related to the SCE. Potentiodynamic polarization studies were measured at a scan rate of $1 \mathrm{mV} \cdot \mathrm{s}^{-1}$ in the potential range between -1 and $0.9 \mathrm{mV}$. The breakdown or pitting potential was attained at the potential where there was a monotonic rise in the current density. The repassivation potential $\left(\mathrm{E}_{\mathrm{pp}}\right)$ is the potential at which the reverse scan comes across the passive region. Electrochemical impedance studies were done in the same setup as potentiodynamic polarization studies and the applied ac perturbation signal was about $5 \mathrm{mV}$ within the frequency range $10^{-2} \mathrm{~Hz}-100 \mathrm{kHz}$. All impedance measurements were carried out under open circuit potential $(\mathrm{OCP})$ conditions. The best achieved data were taken using internally existing software. Individual electrochemical experiments were repeated 3 times to confirm the reproducibility.

\subsection{Simulated Body Fluid (SBF) Solution Preparation}

The standard SBF solution was prepared according to Kokubo's protocol [52] with $\mathrm{NaCl}, \mathrm{NaHCO}_{3}$, $\mathrm{KCl}, \mathrm{K}_{2} \mathrm{HPO}_{4} \cdot \mathrm{H}_{2} \mathrm{O}, \mathrm{MgCl}_{2} \cdot 6 \mathrm{H}_{2} \mathrm{O}, \mathrm{CaCl}_{2}, \mathrm{HCl}(1 \mathrm{M}), \mathrm{Na}_{2} \mathrm{SO}_{4}$, and $\mathrm{NH}_{2} \mathrm{C}\left(\mathrm{CH}_{2} \mathrm{OH}\right)_{3}$. The reagents were dissolved into double distilled water, and $1 \mathrm{M} \mathrm{HCl}$ was used to maintain $\mathrm{pH}$ at 7.4 at $37^{\circ} \mathrm{C}$. The inorganic ion concentrations in the standard SBF solution are almost the same as in human blood plasma. The bioactivity test was carried out by soaking the coated samples attached vertically in a special platinum holder in $45 \mathrm{~mL}$ of SBF in a polyethylene vessel maintained at $37^{\circ} \mathrm{C}$ for $7,14,21$ and 28 days. The SBF solution was renewed every day in order to preserve the ion concentration.

\subsection{In Vitro Biocompatibility Analysis}

\subsubsection{Cell Cultures}

Human osteoblast-like MG-63 cells were purchased from NCCS, Pune, India. The cultured MG-63 cells in $25 \mathrm{~cm}^{2}$ cell culture flask at $37^{\circ} \mathrm{C}$ in Dulbecco's Modified Eagle Medium (DMEM) were combined with $10 \%$ fetal bovine serum (FBS) and incubated at $37^{\circ} \mathrm{C}$ in $5 \% \mathrm{CO}_{2}$ for $3,7,14$ and 21 days. The seeded cells were incubated overnight to allow cell adherence, again at $37^{\circ} \mathrm{C}$ in $5 \%$ $\mathrm{CO}_{2}$ atmosphere, and further used for cell viability studies on the Mn-HAp, $\mathrm{ZnO}$ and Mn-HAp/ZnO bilayer coated 316L SS substrates.

\subsubsection{Cell Viability}

The coating substrates were placed on the attached MG-63 cells and the number of cells was assessed by MTT (3-(4,5-dimethylthiazol-2-yl)-2,5-diphenyl tetrazoliumbromide) assay on cells incubated at $37{ }^{\circ} \mathrm{C}$ in $5 \% \mathrm{CO}_{2}$ for $3,7,14$ and 21 days. All coated samples were washed using sterilized phosphate buffered saline (PBS). MG-63 cells were seeded in 12-well plates at $10^{4}$ cells $/ \mathrm{mL}$ in a humidified $5 \% \mathrm{CO}_{2}$ atmosphere. After $48 \mathrm{~h}$ of incubation, MTT solution in $1 \mathrm{~mL}$ serum-free medium was added and incubated with $5 \% \mathrm{CO}_{2}$, at $37^{\circ} \mathrm{C}$. The data were reported separately for each well by an ELISA reader (Spectra Max 190-microplate reader, Molecular Devices, Delhi, India) at absorbance wavelength $570 \mathrm{~nm}$.

\subsubsection{Cell Adhesion Test}

Mn-HAp, ZnO, Mn-HAp/ZnO bilayer coatings on the 316L SS samples at 10 days of osteoblast-like cells $\left(1 \times 10^{5} / \mathrm{cm}^{2}\right)$ were added on the surface of the specimens and incubated in DMEM supplemented with $10 \%$ FBS at $37^{\circ} \mathrm{C}$ under standard culture conditions. The coating samples were fixed with $2.5 \%$ glutaraldehyde in $0.1 \mathrm{M}$ PBS buffer for $20 \mathrm{~min}$ and washed 3 times with PBS for $5 \mathrm{~min}$ at room temperature. Consequently, each sample was subjected to graded dehydration with pure ethyl alcohol for $10 \mathrm{~min}$ at room temperature. The final samples were gold sputter coated for FESEM analysis. 


\subsubsection{Live/Dead Assay}

MG-63 osteoblasts were added in $2 \mathrm{~mL}$ of culture medium. MG-63 cells were detached from the culture plate using trypsin/EDTA. The plate was incubated at $37{ }^{\circ} \mathrm{C}$ and $5 \% \mathrm{CO}_{2}$ in the dark for 1 and 5 days. Live/dead stain was prepared by adding $2 \mu \mathrm{mol} / \mathrm{L}$ acetomethoxy derivate of calcein (calcein-AM) and $2 \mu \mathrm{mol} / \mathrm{L}$ ethidium homodimer-1 per milliliter of media. The construct was then left in the incubator for $30 \mathrm{~min}$; afterward, the dye was removed and replaced with $1 \mathrm{~mL}$ of DMEM. The ratio of live to dead cells was determined by calculating the number of cells in 3 fields at equal magnification for each Mn-HAp, $\mathrm{ZnO}$, and Mn-HAp/ZnO bilayer coating on 316L SS alloy.

\section{Conclusions}

Bioactive Mn-HAp/ZnO bilayer coating on 316L SS was successfully developed by electrodeposition. The synthesized bilayer coating has improved corrosion resistance, mechanical properties, metal ion leach-out performance, and in vitro bioactivity and biocompatibility. The surface morphology of the bilayer coating has a uniform porous structure and strong adherent coating onto the 316L SS surface. The electrochemical results confirm that the bilayer coating displays excellent corrosion protection when compared to individual coatings in SBF solution. The presence of $\mathrm{ZnO}$ coating improves the mechanical strength, whereas the leach-out analysis showed a reduced rate of metal ion dissolution. Moreover, the in vitro bioactivity results indicate well-defined apatite growth. The coating on 316L SS implants shows high cell attachment and proliferation of Mn-HAp/ZnO bilayer coatings. These are the potential materials for bone repair and regeneration.

Author Contributions: Conceptualization: K.P.A. and J.B.; Methodology: K.P.A. and J.S.; Writing-Original Draft Preparation: K.P.A.; Writing review and Editing: K.P.A., J.B.; Supervision: J.B.; Software and Formal Analysis: K.P.A. and J.S.

Funding: The Shenzhen Key Laboratory financially supported this work for Additive Manufacturing of High-performance Materials, Department of Mechanical and Energy Engineering, Southern University of Science and Technology. Grant No. ZDSYS201703031748354.

Conflicts of Interest: The authors declare no conflict of interest.

\section{References}

1. Le, X.T.; Zeb, G.; Jegou, P.; Berthelot, T. Electrografting of stainless steel by the diazonium salt of 4-aminobenzylphosphonic acid. Electrochim. Acta 2012, 71, 66-72. [CrossRef]

2. Balaceanu, M.; Petreus, T.; Braic, V.; Zoita, C.N.; Vladescu, A.; Cotrutz, C.E.; Braic, M. Characterization of Zr-based hard coatings for medical implant applications. Surf. Coat. Technol. 2010, 204, 2046-2050. [CrossRef]

3. Sharifnabi, A.; Fathi, M.H.; Yekta, B.E.; Hossainalipour, M. The structural and bio-corrosion barrier performance of Mg-substituted fluorapatite coating on 316L stainless steel human body implant. Appl. Surf. Sci. 2014, 288, 331-340. [CrossRef]

4. Azar, B.; Hashemi, B.; Mahboobeh, R. The effect of shot peening on fatigue and corrosion behavior of 316L stainless steel in Ringer's solution. Surf. Coat. Technol. 2010, 204, 3546-3551. [CrossRef]

5. Meth, S.; Savchenko, N.; Koltypin, M.; Starosvetsky, D.; Viva, F.A.; Groysman, A.; Sukenik, C.N. Corrosion studies of stainless steel protected by a $\mathrm{TiO}_{2}$ thin film deposited on a sulfonate-functionalized self-assembled monolayer. Corros. Sci. 2010, 52, 125-129. [CrossRef]

6. Sanctis, D.; Gomez, L.; Pellegri, N.C.; Parodi, N.; Marajofsky, A.; Duran, A. Protective glass coatings on metallic substrates. J. Non-Cryst. Solids 1990, 121, 338-343. [CrossRef]

7. Bornapour, M.; Muja, N.; Shum-Tim, D.; Cerruti, M.; Pekguleryuz, M. Biocompatibility and biodegradability of Mg-Sr alloys: The formation of Sr-substituted hydroxyapatite. Acta Biomater. 2013, 9, 5319-5330. [CrossRef] [PubMed]

8. Gao, J.H.; Guan, S.K.; Chen, J.; Wang, L.G.; Zhu, S.J.; Hu, J.H. Fabrication and characterization of rod-like nano-hydroxyapatite on MAO coating supported on Mg-Zn-Ca alloy. Appl. Surf. Sci. 2011, 257, 2231-2237. [CrossRef] 
9. Gopi, D.; Murugan, N.; Ramya, S.; Kavitha, L. Electrodeposition of a porous strontium substituted hydroxyapatite/zinc oxide duplex layer on AZ91 magnesium alloy for orthopedic applications. J. Mater. Chem. B 2014, 2, 5531-5540. [CrossRef]

10. Schmidt-Mende, L.D.; Macmanus-Driscoll, J.L. ZnO-nanostructures, defects, and devices. Mater. Today 2007, 10, 40-48. [CrossRef]

11. Yang, H.L.; Lin, F.C.; Han, E.H. Effects of P/B on the properties of anticorrosive coatings with different particle size. Prog. Org. Coat. 2005, 53, 91-98. [CrossRef]

12. Dhoke, S.K.; Khanna, A.S.; Sinha, T.J. Effect of nano-ZnO particles on the corrosion behavior of alkyd-based waterborne coatings. Prog. Org. Coat. 2009, 64, 371-382. [CrossRef]

13. Shi, H.; Liu, F.; Han, E.; Wei, Y. Effects of Nano pigments on the corrosion resistance of alkyd coating. J. Mater. Sci. Technol. 2007, 23, 551-558.

14. Dorozhkin, S.V. Calcium orthophosphate-based biocomposites and hybrid biomaterials. J. Mater. Sci. 2009, 44, 2343-2387. [CrossRef]

15. Meurice, E.; Leriche, A.; Hornez, J.C.; Bouchart, F.; Rguti, E.; Boilet, L.; Descampsa, M.; Cambier, F. Functionalisation of porous hydroxyapatite for bone substitutes. J. Eur. Ceram. Soc. 2012, 32, 673-2678. [CrossRef]

16. Abdel-Aal, E.A.; Dietrich, D.; Steinhaeuser, S.; Wielage, B. Electrocrystallization of nanocrystallite calcium phosphate coatings on titanium substrate at different current densities. Surf. Coat. Technol. 2008, 202, 5895-5900. [CrossRef]

17. Elliott, J.C. Structure and Chemistry of the Apatites and Other Calcium Orthophosphates; Elsevier: Amsterdam, The Netherland, 1994.

18. Boanini, E.; Gazzano, M.; Bigi, A. Ionic substitutions in calcium phosphates synthesized at low temperature. Acta Biomater. 2010, 6, 1882-1894. [CrossRef] [PubMed]

19. Bigi, A.; Cojazzi, G.; Panzavolta, S.; Ripamonti, A.; Roveri, N.; Romanello, M.; Noris, S.K.; Moro, L. Chemical and structural characterization of the mineral phase from cortical and trabecular bone. J. Inorg. Biochem. 1997, 68, 45-51. [CrossRef]

20. Gaines, R.V.; Skinner, H.C.V.; Foord, E.F.; Mason, B.; Rosenzweig, A. Dana's New Mineralogy; Wiley: New York, NY, USA, 1997.

21. Mayer, I.; Cuisinier, F.J.G.; Gdalya, S.; Popov, I. TEM study of the morphology of Mn doped calcium hydroxyapatite and b-tri-calcium phosphate. J. Inorg. Biochem. 2008, 102, 311-317. [CrossRef] [PubMed]

22. Sopyan, I.; Ramesh, S.; Nawaw, N.A.; Tampieri, A.; Sprio, S. Effects of manganese doping on properties of sol-gel derived biphasic calcium phosphate ceramics. Ceram. Int. 2011, 37, 3703-3715. [CrossRef]

23. Park, J.W.; Kim, Y.J.; Jang, J.H. Surface characteristics and in vitro biocompatibility of a manganese-containing titanium oxide surface. Appl. Surf. Sci. 2011, 258, 977-985. [CrossRef]

24. Singh, G.; Singh, H.; Sidhu, B.S. In vitro, corrosion investigations of plasma-sprayed hydroxyapatite and hydroxyapatite-calcium phosphate coatings on 316L SS. Bull. Mater. Sci. 2014, 37, 1519-1528. [CrossRef]

25. Marvis, B.C.; Tas, A.C. Dip Coating of calcium hydroxyapatite on Ti-6Al-4V substrates. J. Am. Ceram. Soc. 2000, 83, 989-991. [CrossRef]

26. Subramanian, B.; Ananthakumar, R. Surface modification of 316L stainless steel with magnetron sputtered TiN/VN nanoscale multilayers for bio implant applications. J. Mater. Sci. Mater. Med. 2012, 23, 329-338. [CrossRef] [PubMed]

27. Wang, Z.C.; Ni, Y.J.; Huang, J.C. Fabrication and characterization of $\mathrm{HAp} / \mathrm{Al}_{2} \mathrm{O}_{3}$ composite cating on titanium substrate. J. Biomed. Sci. Eng. 2008, 1, 190-194. [CrossRef]

28. Wei, M.; Ruys, A.J.; Milthorpe, B.K.; Sorrell, C.C.; Evans, J.H. Electrophoretic deposition of hydroxyapatite coatings on metal substrates: A nanoparticulate dual-coating approach. J. Sol-Gel Sci. Technol. 2001, 21, $39-48$. [CrossRef]

29. Xiao, X.F.; Liu, R.F.; Zheng, Y.Z. Haracterization of hydroxyapatite/Ti6Al4V composite powder under various sintering temperature. Surf. Coat. Technol. 2006, 200, 4406-4413. [CrossRef]

30. Song, Y.; Zhang, S.; Li, J.; Zhao, S.; Zhang, X. Electrodeposition of Ca-P coatings on biodegradable Mg alloy: In vitro biomineralization behavior. Acta Biomater. 2010, 6, 1736-1742. [CrossRef] [PubMed]

31. Djosic, M.S.; Panic, V.; Stojanovic, J.; Mitric, M.; MiskovicStankovic, V.B. The effect of applied current density on the surface morphology of deposited calcium phosphate coatings on titanium. Colloids. Surf. A Physicochem. Eng. Asp. 2012, 400, 36-43. [CrossRef] 
32. Zhang, L.; Ma, A.; Jiang, J.; Song, D.; Chen, J.; Yang, D. Anti-corrosion performance of waterborne Zn-rich coating with modified silicon-based vehicle and lamellar $\mathrm{Zn}(\mathrm{Al})$ pigments. Prog. Nat. Sci. Mater. Int. 2012, 22, 326-333. [CrossRef]

33. Hong, R.Y.; Li, J.H.; Chen, L.L.; Liu, D.Q.; Li, H.Z.; Zheng, Y.; Ding, J. Synthesis, surface modification and photocatalytic property of ZnO nanoparticles. Powder Technol. 2009, 189, 426-432. [CrossRef]

34. Kumar, R.; Prakash, K.H.; Cheang, P.; Khor, K.A. Temperature driven morphological changes of chemically precipitated hydroxyapatite nanoparticles. Langmuir 2004, 20, 5196-5200. [CrossRef] [PubMed]

35. Jagtap, R.N.; Nambiar, R.; Zaffar, H.S.; Malshe, V.C. Predictive power for life and residual life of the zinc rich primer coatings with electrical measurement. Prog Org Coat. 2007, 58, 253-258. [CrossRef]

36. Rajendran, S.P.; Sengodan, K. Synthesis and characterization of zinc oxide and iron oxide nanoparticles using sesbania grandiflora leaf extract as reducing agent. J. Nanoscience 2017, 2017, 1-7. [CrossRef]

37. Ananth, K.P.; Nathanael, A.J.; Jose, S.P.; Oh, T.H.; Mangalaraj, D. A novel silica nanotube reinforced ionic incorporated hydroxyapatite composite coating on polypyrrole coated 316L SS for implant application. Mater. Sci. Eng. C 2016, 59, 1110-1124. [CrossRef] [PubMed]

38. Gogurla, N.; Sinha, A.K.; Santra, S.; Manna, S.; Ray, S.K. Multifunctional au-zno plasmonic nanostructures for enhanced uv photodetector and room temperature no sensing devices. Sci. Rep. 2014, 4, 6483. [CrossRef] [PubMed]

39. Hongbo, B.L.; Campbell, T.C.; Graham, T.J.; Ratner, B.D. Surface characterization of hydroxyapatite and related calcium phosphates by xps and tof-sims. Anal. Chem. 2000, 72, 2886-2894.

40. Vijayalakshmi, U.; Rajeswari, R. Influence of process parameters on the sol-gel synthesis of nano hydroxyapatite using various phosphorus precursors. J. Sol-Gel Sci. Technol. 2012, 63, 45-55. [CrossRef]

41. Karthikeyan, P.; Malathy, M.; Rajavel, R. Poly(ophenylenediaminecoaniline)/ZnO coated on passivated low nickel stainless steel. J. Sci. Adv. Mater. Device 2016, 2, 86-92. [CrossRef]

42. Lopez, D.Z.; Simison, S.N.; de Sánchez, S.R. The influence of steel microstructure on $\mathrm{CO}_{2}$ corrosion. EIS studies on the inhibition efficiency of benzimidazole. Electrochem. Acta 2003, 48, 845-854. [CrossRef]

43. Motalebi, A.; Nasr-Esfahani, M.; Ali, R.; Pourriahi, M. Improvement of corrosion performance of 3161 stainless steel via pvtms/henna thin film. Prog. Nat. Sci. Mater. Int. 2012, 22, 392-400. [CrossRef]

44. Savaloni, H.; Agha-Taheri, E.; Abdi, F. On the corrosion resistance of AISI 316L-type stainless steel coated with manganese and annealed with flow of oxygen. J. Theor. Appl. Phys. 2016, 10, 149-156. [CrossRef]

45. Ostomel, T.A.; Shi, Q.; Tsung, C.K. Spherical bioactive glass with enhanced rates of hydroxyapatite deposition and hemostatic activity. Small 2006, 2, 1261-1265. [CrossRef] [PubMed]

46. Zhaoa, Q.; Guo, X.; Dangb, X.; Hao, J.; Lai, J.; Wang, K. Preparation and properties of composite MAO/ECD coatings on magnesium alloy. Colloids Surf. B Biointerface 2013, 102, 321-336. [CrossRef] [PubMed]

47. Breitwieser, G.E. Extracellular calcium as an integrator of tissue function. Int. J. Biochem. Cell Biol. 2008, 40, 1467-1480. [CrossRef] [PubMed]

48. Raimondo, T.; Puckett, S.; Webster, T.J. Greater osteoblast and endothelial cell adhesion on nanostructured polyethylene and titanium. Int. J. Nanomed. 2010, 5, 647-652.

49. Liu, G.; Li, G.; Qiu, X.; Li, L. Synthesis of ZnO/titanate nanocomposites with highly photocatalytic activity under visible light irradiation. J. Alloys Compd. 2009, 481, 492-497. [CrossRef]

50. Lin, D.Y.; Wang, X.X. Preparation of hydroxyapatite coating on smooth implant surface by electrodeposition. Ceram. Int. 2011, 37, 403-406. [CrossRef]

51. ASTM Standard F 1044-05; ASTM International: West Conshohocken, PA, USA, 2005.

52. Kokubo, T.; Takadama, T. How useful is SBF in predicting in vivo bone bioactivity? Biomaterials 2006, 27, 2907-2915. [CrossRef] [PubMed]

(C) 2018 by the authors. Licensee MDPI, Basel, Switzerland. This article is an open access article distributed under the terms and conditions of the Creative Commons Attribution (CC BY) license (http:/ / creativecommons.org/licenses/by/4.0/). 